\title{
Controlled oxygen release from pyridone endoperoxides promotes cell survival under anoxic conditions
}

\author{
Benz, Sebastian ; Noetzli, Sarah ; Siegel, Jay ; Eberli, Daniel ; Jessen, Henning Jacob
}

\begin{abstract}
In tissue engineering, survival of larger constructs remains challenging due to limited supply with oxygen caused by a lack of early vascularization. Controlled release of oxygen from small organic molecules represents a possible strategy to prevent cell death under anoxic conditions. A comprehensive study of methylated pyridone-derived endoperoxides has led to the development of water-soluble molecules that undergo retro Diels-Alder reactions in aqueous environment releasing oxygen in high yield and with half-lives of up to 13 hours. These molecules in combination with vitamin $\mathrm{C}$ as singlet oxygen quencher significantly improved survival of 3T3 fibroblasts and rat smooth muscle cells challenged with oxygendepleted conditions.
\end{abstract}

DOI: https://doi.org/10.1021/jm4016137

Posted at the Zurich Open Repository and Archive, University of Zurich ZORA URL: https://doi.org/10.5167/uzh-85950

Journal Article

Accepted Version

Originally published at:

Benz, Sebastian; Noetzli, Sarah; Siegel, Jay; Eberli, Daniel; Jessen, Henning Jacob (2013). Controlled oxygen release from pyridone endoperoxides promotes cell survival under anoxic conditions. Journal of Medicinal Chemistry, 56(24):10171-10182.

DOI: https://doi.org/10.1021/jm4016137 


\section{Controlled oxygen release from pyridone}

\section{endoperoxides promotes cell survival under anoxic}

\section{conditions}

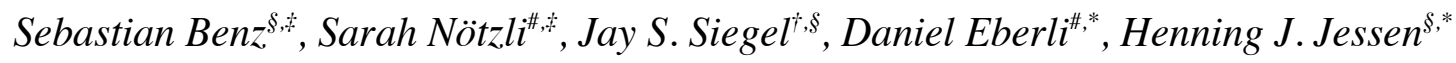

${ }^{\S}$ University of Zürich, Institute of Organic Chemistry, Winterthurerstrasse 190, 8057 Zürich, Switzerland. " University of Zürich, University Hospital, Department of Urology, Frauenklinikstrasse 10, 8091, Zürich, Switzerland.

ABSTRACT. In tissue engineering, survival of larger constructs remains challenging due to limited supply with oxygen caused by a lack of early vascularization. Controlled release of oxygen from small organic molecules represents a possible strategy to prevent cell death under anoxic conditions. A comprehensive study of methylated pyridone-derived endoperoxides has led to the development of water-soluble molecules that undergo retro Diels-Alder reactions in aqueous environment releasing oxygen in high yield and with half-lives of up to 13 hours. These molecules in combination with vitamin $\mathrm{C}$ as singlet oxygen quencher significantly improved survival of $3 \mathrm{~T} 3$ fibroblasts and rat smooth muscle cells challenged with oxygen-depleted conditions. 
INTRODUCTION. The support of anoxic tissue with oxygen to enhance cell survival holds promise in different areas of medical research and applications. In regenerative medicine, necrosis of engineered tissue as a result of oxygen depletion has remained a challenging problem, especially in larger grafts. ${ }^{1-7}$ The efficiency of oxygen supply in engineered grafts is reduced, due to the poor vascularization ${ }^{8-10}$ of these implants and the diffusion limit of molecular oxygen. ${ }^{11}$ Necrosis and apoptosis of cells in engineered grafts and a shift to anaerobic metabolism controlled by hypoxia-inducible factor 1 (HIF-1) ${ }^{12,13}$ under oxygen-deprived conditions can impair the healing process significantly. As a result of coagulative necrosis, cell debris and denatured proteins accumulate and further reduce oxygen supply causing failure in vital functions of the tissue. Thus, effort has been dedicated to the development of techniques that can supply oxygen to hypoxic/anoxic tissue (see notes at the end of the paper).$^{5,14-16} \mathrm{An}$ intriguing strategy is the use of (biodegradable) polymers as scaffolds that slowly release oxygen in the graft. ${ }^{17-20}$ The release must occur on a time-scale enabling the growth of a vascular network that can eventually support engineered tissue autonomously. From this perspective, the release of oxygen should occur over several days. ${ }^{21}$ The molecules that have been studied in tissue engineering of bones and cardiosphere derived stem-cell therapy are hydrogen peroxide, sometimes combined with catalase,$^{18}$ and in the context of pancreatic islet regeneration, ${ }^{20}$ inorganic peroxides such as calcium peroxide that eventually produce hydrogen peroxide. ${ }^{22}$ Soaking of biocompatible polymers such as poly(lactic-co-glycolic acid) (PLGA ${ }^{23}$ has led to promising results, showcasing the possibility to rescue hypoxic tissue and, as a consequence, decrease necrosis of tissue over multiple days in a naked mouse skin flap model.${ }^{17}$ However, an issue can be the cytotoxicity of the $\mathrm{H}_{2} \mathrm{O}_{2}$ /catalase mixture or, more general, uncontrolled release of oxygen and ions such as $\mathrm{Ca}^{2+} \cdot 24,25$ On this account, endoperoxides incorporated into small 
organic molecules are interesting alternatives owing to their ability to release oxygen in a retro Diels-Alder reaction following first order kinetics. ${ }^{26}$ The reaction rate can likely be controlled by the substitution pattern on the scaffold and does not rely on the presence of enzymes or other triggers. Moreover, these scaffolds could be attached covalently to a solid support, opening up the possibility to synthesize oxygen-releasing polymers with defined rates of oxygen release and without soluble byproducts, such as calcium ions. Systems that have been shown to reversibly incorporate oxygen are derived from polyaromatic hydrocarbons like e.g. naphthalene and anthracene or different 2-pyridones. ${ }^{27-31}$ The latter provide a scaffold that allows straightforward generation of interesting substitution patterns, whilst their polar nature should enhance solubility in water as compared to e.g. anthracene-derived endoperoxides. Thus, the controlled release of oxygen from substituted 2-pyridone-derived endoperoxides in aqueous environment followed by subsequent quenching ${ }^{32}$ of initially formed ${ }^{1} \mathrm{O}_{2}$ to ${ }^{3} \mathrm{O}_{2}$ e.g. by solvent deactivation ${ }^{33}$ potentially provides a new strategy to rescue anoxic tissue from necrosis.

CHEMISTRY. To study the rate and efficiency of oxygen release from pyridone-derived endoperoxides, a series of substituted 2-pyridones had to be obtained and then subjected to type two photooxygenations..$^{34}$ It has been shown in naphthalene-derived endoperoxides, that substituting the bridgehead position significantly decreases the rate of the retro Diels-Alder reaction..$^{30,35}$ As one goal was the attenuated release of oxygen to prolong tissue supply and reduce oxygen-related toxicity, a series of methylated 2-pyridones was targeted to study the effect of simple substituents and combinations thereof in the system. In this context, the yield of oxygen release in water is clearly another important parameter. To increase the overall stability of the pyridone endoperoxides ${ }^{34}$ and their solubility in water, a short triethylene glycol ether moiety was attached to the pyridone via $N$-alkylation that strongly reduced lipophilicity (see 
table 1, ClogP values). As starting materials for the synthesis, some (methylated) 2-pyridones, such as $\mathbf{9}$ and 10, are commercially available, others had to be obtained by chemical transformations (see Scheme 1).

Briefly, 2-bromo-6-methylpyridine 1 was treated with sodium methoxide in methanol under microwave irradiation for 1 hour and the intermediate methoxypyridine was directly converted into the 6-methyl-2-pyridone 2 with hydrochloric acid in 1,4-dioxane at $100^{\circ} \mathrm{C}$ in $70 \%$ yield over both steps. ${ }^{36}$

2,5-Lutidine $\mathbf{3}$ was selectively brominated with one equivalent of tribromoisocyanuric acid $(\mathrm{TBCA})^{37}$ in $20 \%$ oleum giving an intermediate dibromide ${ }^{38}$ in $89 \%$ yield after stirring for three hours at room temperature. Nucleophilic substitution of bromide with sodium methoxide in methanol under microwave irradiation delivered 2-methoxypyridine derivative 4. Lithium bromide exchange yielded the 3,6-dimethyl-2-pyridone $\mathbf{5}$ after protonation of the lithiated intermediate with water and cleavage of the methyl ether. Alternatively, reaction of the lithiated intermediate with methyl iodide delivered the 3,5,6-trimethyl-2-pyridone ${ }^{39} \mathbf{6}$ after cleavage of the methyl ether.

3,5-Lutidine 7 was converted with meta-chloroperbenzoic acid into its corresponding $\mathrm{N}$-oxide, which was first treated with acetic acid anhydride and then with water at elevated temperature giving 3,5-dimethyl-2-pyridone $\mathbf{8}^{40}$

The series of 2-pyridones was $N$-alkylated with 2-[2-(2-methoxyethoxy)ethoxy]ethyl 2bromoacetate. ${ }^{41}$ Careful adjustment of the reaction conditions for each 2-pyridone was necessary to control $\mathrm{N}$ - versus $O$-alkylation. ${ }^{42}$ The ester moiety was important, as otherwise the endoperoxide could not be stably incorporated into the scaffold.$^{34}$ It should be noticed that this is 
also a suitable attachment point for covalent linkage to different polymers. The synthetic and commercially available 2-pyridones 11-16 were converted into their endoperoxides 17-22 by type two photooxygenations using triplet oxygen and tetraphenylporphyrin (TPP) as a sensitizer under irradiation with a high-pressure sodium lamp. ${ }^{43,44}$ The Diels-Alder reactions occurred smoothly and with high yield within one hour in DCM at $0^{\circ} \mathrm{C}$. The products were purified by flash column chromatography over $\mathrm{SiO}_{2}$. All endoperoxides were stable over a period of many months if stored appropriately at $-20^{\circ} \mathrm{C}$. 
Scheme 1. Synthesis of substituted 2-pyridones and their corresponding endoperoxides. ${ }^{\text {a }}$<smiles>Cc1cccc(=O)[nH]1</smiles>

$70 \% 2$<smiles>COc1nc(C)c(Br)cc1C</smiles>

$79 \% 4$

$d$ or e
then $b$

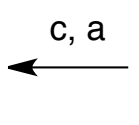<smiles>Cc1ccc(C)nc1</smiles>

3<smiles>Cc1c[nH]c(=O)c(C)c1</smiles>

$23 \% 8$<smiles>Cc1cncc(C)c1</smiles>

7

$$
\mathrm{R}=\mathrm{H} ; 68 \% 5
$$

$$
\mathrm{R}=\mathrm{CH}_{3} ; 63 \% 6
$$
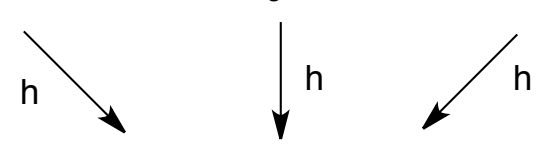<smiles>[R]c1ccc[nH]c1=O</smiles>

$\mathrm{R}=\mathrm{H} ; \boldsymbol{9}$

$\mathrm{R}=\mathrm{CH}_{3} ; \mathbf{1 0}$

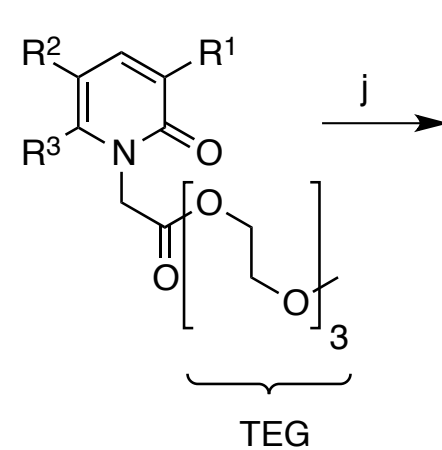

$$
\begin{aligned}
& R^{1}=R^{2}=R^{3}=H ; 76 \% 11 \\
& R^{1}=C_{3} ; R^{2}=R^{3}=H ; 35 \% 12 \\
& R^{1}=R^{2}=H ; R^{3}=\mathrm{CH}_{3} ; 28 \% 13 \\
& R^{1}=R^{2}=\mathrm{CH}_{3} ; R^{3}=\mathrm{H} ; 50 \% 14 \\
& \mathrm{R}^{1}=\mathrm{R}^{3}=\mathrm{CH}_{3} ; \mathrm{R}^{2}=\mathrm{H} ; 41 \% 15 \\
& \mathrm{R}^{1}=\mathrm{R}^{2}=\mathrm{R}^{3}=\mathrm{CH}_{3} ; 67 \% 16
\end{aligned}
$$

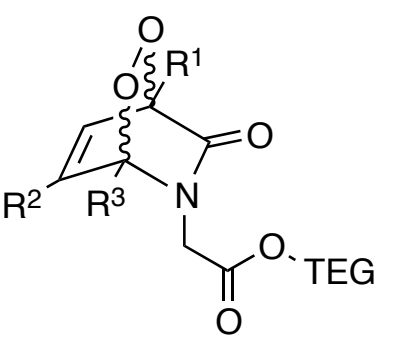

$\mathrm{R}^{1}=\mathrm{R}^{2}=\mathrm{R}^{3}=\mathrm{H} ; 95 \% 17$

$\mathrm{R}^{1}=\mathrm{CH}_{3} ; \mathrm{R}^{2}=\mathrm{R}^{3}=\mathrm{H} ; 70 \% 18$

$R^{1}=R^{2}=H ; R^{3}=C_{3} ; 95 \% 19$

$\mathrm{R}^{1}=\mathrm{R}^{2}=\mathrm{CH}_{3} ; \mathrm{R}^{3}=\mathrm{H} ; 75 \% 20$

$\mathrm{R}^{1}=\mathrm{R}^{3}=\mathrm{CH}_{3} ; \mathrm{R}^{2}=\mathrm{H} ; 97 \% 21$

$\mathrm{R}^{1}=\mathrm{R}^{2}=\mathrm{R}^{3}=\mathrm{CH}_{3} ; 95 \% 22$

${ }^{\mathrm{a}}$ Reagents and conditions a) 4 eq. $\mathrm{NaOMe}, \mathrm{MeOH}$, microwave $100{ }^{\circ} \mathrm{C}$, $1 \mathrm{~h}$; b) $\mathrm{HCl}$ conc. / 1,4Dioxane, microwave $100{ }^{\circ} \mathrm{C}, 2 \mathrm{~h}$; c) 1 eq. TBCA, Oleum $20 \% \mathrm{SO}_{3}, 2.5 \mathrm{~h}$; d) i. 1.1 eq. $n$-BuLi THF, $-78^{\circ} \mathrm{C}$, ii. $\mathrm{H}_{2} \mathrm{O}, 0{ }^{\circ} \mathrm{C}$ to RT; e) i. 1.1 eq. $n$-BuLi, THF, $-78{ }^{\circ} \mathrm{C}$, ii. 3 eq. MeI, $-78{ }^{\circ} \mathrm{C}$ to RT; f) 1.1 eq. $m$ CPBA, DCM, RT, 5h; g) i. $\mathrm{Ac}_{2} \mathrm{O}$, reflux, 20 h, ii. $\mathrm{H}_{2} \mathrm{O}$, reflux, 2h; h) i. 1.1 eq. $\mathrm{NaH}$, $\mathrm{DME} / \mathrm{DMF}, \quad 0{ }^{\circ} \mathrm{C}, 15 \mathrm{~min}, \quad$ ii. 2.0 eq. $\mathrm{LiBr}, \mathrm{RT}, 15 \mathrm{~min}$, iii. 2.0 eq 2-[2-(2Methoxyethoxy)ethoxy] ethyl 2-bromoacetate, $65^{\circ} \mathrm{C}$, 4-12h; i) 3.0 eq. $\mathrm{K}_{2} \mathrm{CO}_{3}$, then 1.5 eq 2-[2(2-Methoxyethoxy)ethoxy]ethyl 2-bromoacetate, DMF, overnight, RT; j) TPP cat., hv, DCM, 0 ${ }^{\circ} \mathrm{C}, 1 \mathrm{~h}$. 
BIOLOGY. For the evaluation of cell expansion, $3 \mathrm{~T} 3$ fibroblast cell line and primary smooth muscle cells (SMCs) freshly isolated from rat bladder tissue ${ }^{45}$ were cultured at a density of 4000 cells $/ \mathrm{cm}^{2}$. Endoperoxide 18 or pyridone 12 was dissolved in a 1:50 $\mathrm{H}_{2} \mathrm{O} / \mathrm{DMSO}$ (DMSO Hybri$\operatorname{Max}^{\circledR}$, Sigma, Switzerland) mix and different amounts $(10,50,100$ and $200 \mu \mathrm{g} / \mathrm{mL})$ were directly added to cells in culture medium (CM) consisting of Dulbecco's modified Eagle Medium (DMEM), 10\% fetal bovine serum (FBS) and 1\% Penicillin/Streptomycin (DMEM/F12, GlutaMAX ${ }^{\mathrm{TM}}$ and Pen/Strep, Gibco ${ }^{\oplus}$ HyClone ${ }^{\circledR}$ FBS Defined, ThermoScientific). Vitamin C (Sigma, Switzerland) dissolved in $\mathrm{H}_{2} \mathrm{O}$ was used in different concentrations as antioxidant (100 and $500 \mu \mathrm{g} / \mathrm{mL}$ to fibroblasts; 100 and $200 \mu \mathrm{g} / \mathrm{mL}$ to SMCs) and added to the endoperoxide 18 under the different assay conditions. All experiments were performed in triplicates. Cells with or without additives served as controls. Further, the parent pyridone 12 (the other product of the retro Diels-Alder process of $\mathbf{1 8}$ besides oxygen) was tested with SMCs only.

All tests were performed in normoxic (aerobic, $37^{\circ} \mathrm{C}, 5 \% \mathrm{CO}_{2}$ ) and anoxic environment $\left(\mathrm{N}_{2}\right)$. For the anoxic condition, $\mathrm{CM}$ was degassed prior to use with $\mathrm{N}_{2}$ for 2-3 hours (continuous bubbling of $\mathrm{N}_{2}$ through a sterile tube into the medium). The experiments were conducted in an $\mathrm{O}_{2}$-free environment by adding nitrogen gas to an airtight bag system (Sekuroka ${ }^{\circledR}-$ Glove-Bags, Carl Roth $\mathrm{GmbH}$, Switzerland). Additionally, the 24-well plates were individually packed in airtight minigrip bags and kept in the incubator $\left(37^{\circ} \mathrm{C}, 5 \% \mathrm{CO}_{2}\right)$ without following medium change for up to 4 days. For the aerobic condition, cells were processed in a laminar flow hood and kept in the same incubator without airtight sealing.

Cell viability was measured on days 1-4 using a colorimetric assay with 2-(4-iodophenyl)-3-(4nitrophenyl)-5-(2,4-disulfophenyl)-2H-tetrazolium monosodium salt reagent (WST-1, Roche, 
Switzerland) according to the supplier. Briefly, CM was substituted with $0.5 \mathrm{~mL} /$ well fresh CM containing $50 \mu \mathrm{L} /$ well WST-1 reagent (1:10). After an incubation time of 3 hours, absorbance of the supernatant was measured at $450 \mathrm{~nm}$ in a scanning multiwell spectrophotometer $\left(\mathrm{KC}^{\mathrm{TM}}\right.$, Software BioTek Instruments, Inc. Luzern, Switzerland).

\section{RESULTS AND DISCUSSION.}

Chemical behavior in water. The half-lives of the retro Diels-Alder process at $37{ }^{\circ} \mathrm{C}$ in $\mathrm{H}_{2} \mathrm{O}$ / $\mathrm{D}_{2} \mathrm{O} 9: 1 \mathrm{v} / \mathrm{v}$ were measured by ${ }^{1} \mathrm{H}-\mathrm{NMR}$ spectroscopy with water suppression assuming first order kinetics. Since the chemical shift of the released 2-pyridones was known, quantification of oxygen release was possible. The half-lives were estimated by fitting of an exponential regression curve and using the equation $t_{1 / 2}=\ln (2) / \mathrm{k}$ (see Scheme 2 ). The obtained values are summarized in the following table 1 .

Scheme 2. Exponential decay of endoperoxide 18 and evolution of parent pyridone $\mathbf{1 2}^{\mathrm{a}}$ in water.
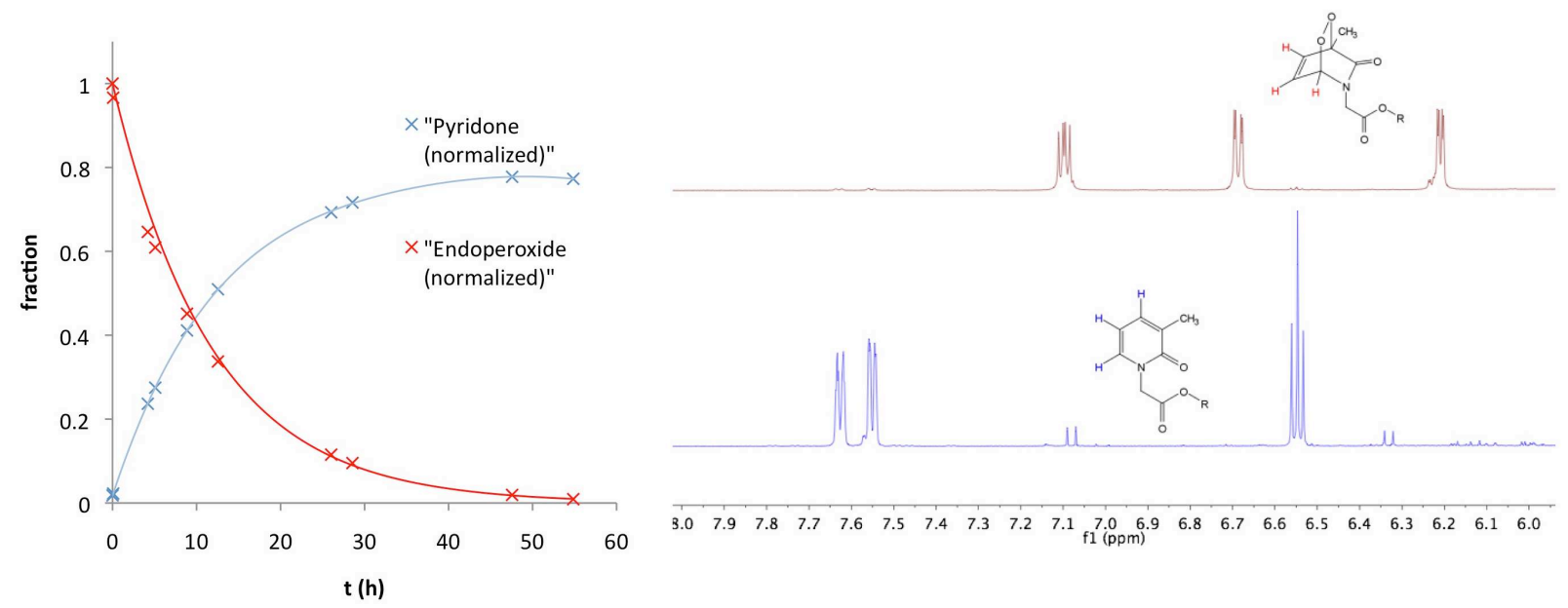

\footnotetext{
${ }^{a}$ Values in the graph (left) are normalized on starting endoperoxide 18 . The values were obtained by integration of explicit proton resonances (right) in the ${ }^{1} \mathrm{H}$ NMR spectrum $\left(\mathrm{H}_{2} \mathrm{O} / \mathrm{D}_{2} \mathrm{O}\right.$ 9:1) and
} 
normalized to resonances of a defined amount of added DMSO. The partial ${ }^{1} \mathrm{H}$ NMR spectrum shows the distinct signals before (red, $0 \mathrm{~h}$ ) and after (blue, $>60 \mathrm{~h}$ ) retro-Diels Alder reaction.

Table 1. ClogP, half-lives and amount of oxygen release from endoperoxides in water at $37^{\circ} \mathrm{C}$.

\begin{tabular}{cccc}
\hline Compound & ClogP $^{\mathrm{a})}$ & $\mathrm{t}_{1 / 2}[\mathrm{~h}]$ & \% retro Diels-Alder \\
\hline $\mathbf{1 7}$ & -0.8 & 0.5 & $18^{\mathrm{b})}$ \\
$\mathbf{1 8}$ & -0.4 & 8.5 & $78^{\mathrm{b})}$ \\
$\mathbf{1 9}$ & -0.4 & 4 & ca. $50^{\mathrm{c})}$ \\
$\mathbf{2 0}$ & 0.0 & 13 & $47^{\mathrm{b})}$ \\
$\mathbf{2 1}$ & 0.0 & 4 & ca. $50^{\mathrm{c})}$ \\
$\mathbf{2 2}$ & 0.1 & 15 & ca. $10^{\mathrm{c})}$ \\
\hline
\end{tabular}

a) ChemDraw Pro (Version 12); b) measurement normalized on DMSO standard; c) not normalized

For endoperoxides $\mathbf{1 7}, \mathbf{1 8}$ and $\mathbf{2 0}$, more precise values were obtained by internal standardization with DMSO. Additionally, the NMR studies were used for an evaluation of the selectivity of the process, as the chemical shifts of the starting 2-pyridone were known. Thus, peaks arising from the retro Diels-Alder process were readily assigned. The 2-pyridone and the endoperoxide that had the most favorable properties, i.e. a long half-life combined with a good yield of oxygen and little byproduct formation, were then examined in cell assays (vide supra). Non-methylated endoperoxide 17 was the least stable in water and decomposed quickly and unspecifically within 30 minutes at $37{ }^{\circ} \mathrm{C}$. This behavior is in contrast to an earlier publication, where oxygen release from a related non-methylated pyridone was measured in chloroform and found to occur slowly and selectively. ${ }^{29}$ Endoperoxide 18 with a methyl group in the 3-position slowly released oxygen in water with a half-life of 8 hours with only little byproduct formation (ca. 20\%, see Figure 1). 
Due to its favorable properties, this compound was eventually chosen for the cell-based assays. Methylation in the 6-position as in 19, 21, 22 opened up new decomposition pathways other than retro Diels-Alder thus increasing byproduct formation (>50\%) and decreasing oxygen yield and half-lives (ca. 4 h). Compound 20 with methyl groups in the 3- and 5- position displayed an increased half-life of about 13 hours and acceptable oxygen yield (50\%). The main byproduct in most of the cases is the rearranged pyridone resulting from the Kornblum-Delamare reaction $^{31,46,47}$ that is triggered both under basic and acidic conditions (results not shown). From these studies it became obvious that modification of the pyridone in the 3 position resulted in favorable properties, whereas methylation e.g. in the 6 position strongly reduced the propensity of the system to undergo retro Diels-Alder reaction.

Cell Viability and Cytotoxicity. The properties of endoperoxide 18 were studied in combination with rat smooth muscle cells (SMCs) and 3T3 Fibroblasts (FBs). These cell lines play important roles in tissue regeneration, as they are constituents of blood vessels and connective tissue, respectively. ${ }^{48-50}$ It is important to notice that their natural environments generally feature hypoxic conditions (sometimes referred to as in situ normoxia), ${ }^{51}$ which might explain the slow growth under normoxic, ambient conditions (actually hyperoxia) that was generally observed in the assays. ${ }^{52}$ Interestingly, fibroblasts contain significantly increased VEGF mRNA if grown under hypoxic conditions,${ }^{53}$ initiating angiogenesis in hypoxic tissue along with other factors.$^{54,55}$ Initially, growth of FB and SMC under normoxic and anoxic conditions was followed and quantified over four days. The untreated control was normalized to $100 \%$ growth rate and compared to cells grown in the presence of additives. Increased growth rate was attributed to improved survival and avoidance of cell-cycle arrest under the respective conditions. ${ }^{19,56}$ From the experimental setup one would expect the following observations: 1) Under normoxic 
conditions the endoperoxide should not lead to growth enhancement. 2) High concentrations of the endoperoxide should reduce cell viability under normoxic conditions, as singlet oxygen is released. ${ }^{57}$ ) The addition of an antioxidant like vitamin $\mathrm{C}$ (physical and chemical quenching of $\left.{ }^{1} \mathrm{O}_{2}\right)^{58}$ should reduce the cytotoxicity exerted by the endoperoxide. 4) Under anoxic conditions the endoperoxide should enhance the normalized growth rate of the cells, if used at non-toxic concentration. 5) small amounts of endoperoxide could already have an effect on the growth rate, as both cell types usually grow under hypoxic conditions. 6) The byproduct of the retro DielsAlder process, the corresponding pyridone, should not have an effect on cell growth both under normoxic and anoxic conditions.

Based on the above considerations, the cytotoxicity of the compounds had to be determined first. The growth rate was quantified after the indicated periods with a colorimetric assay (WST-1, Roche). As expected, the growth rate of both SMCs and FBs was inhibited upon addition of endoperoxide 18 in a concentration-dependent manner. Concentrations of $29 \mu \mathrm{M}(10 \mu \mathrm{g} / \mathrm{mL}) \mathrm{up}$ to $580 \mu \mathrm{M}(200 \mu \mathrm{g} / \mathrm{mL})$ were analyzed and already at the lowest concentration an effect on cell growth was observed under normoxic conditions in both FBs and SMCs (see Graph 2). However, this effect was significantly reduced under anoxic conditions in fibroblasts $(10 \mu \mathrm{g} / \mathrm{mL} \mathbf{1 8})$. Intriguingly, addition of vitamin $\mathrm{C}$ as singlet oxygen quencher $(100 \mu \mathrm{g} / \mathrm{mL})$ led to significant reduction of the cytotoxic effect of endoperoxide $\mathbf{1 8}$ under normoxic conditions and completely abolished the negative effect of $\mathbf{1 8}$ on cell viability under anoxic conditions (see Graph 3 ). High amounts of vitamin $\mathrm{C}(500 \mu \mathrm{g} / \mathrm{mL})$ were usually found to be detrimental in the assays (see graph 2, grey bars), at least after 2 days of incubation, whereas on the first day this concentration pronouncedly increased the rate of cell growth under anoxic conditions (see graph 3, red, green and grey bars) and for very high concentrations of $\mathbf{1 8}$ and vitamin $\mathrm{C}$ also under normoxic 
conditions (see graph 2, blue and yellow bars). From these data it becomes obvious, that the cells react very differently to the application of endoperoxide $\mathbf{1 8}$ under normoxic and anoxic conditions. Given the fact that $100 \mu \mathrm{g} / \mathrm{mL}$ of vitamin $\mathrm{C}$ did not significantly alter the growth rate of cells alone under anoxic conditions (graph 3, light grey bars), this amount was used in the following experiments to distinguish the effect exerted by oxygen release from the endoperoxide.

Graph 2. Normalized growth rate of Fibroblasts under normoxic conditions

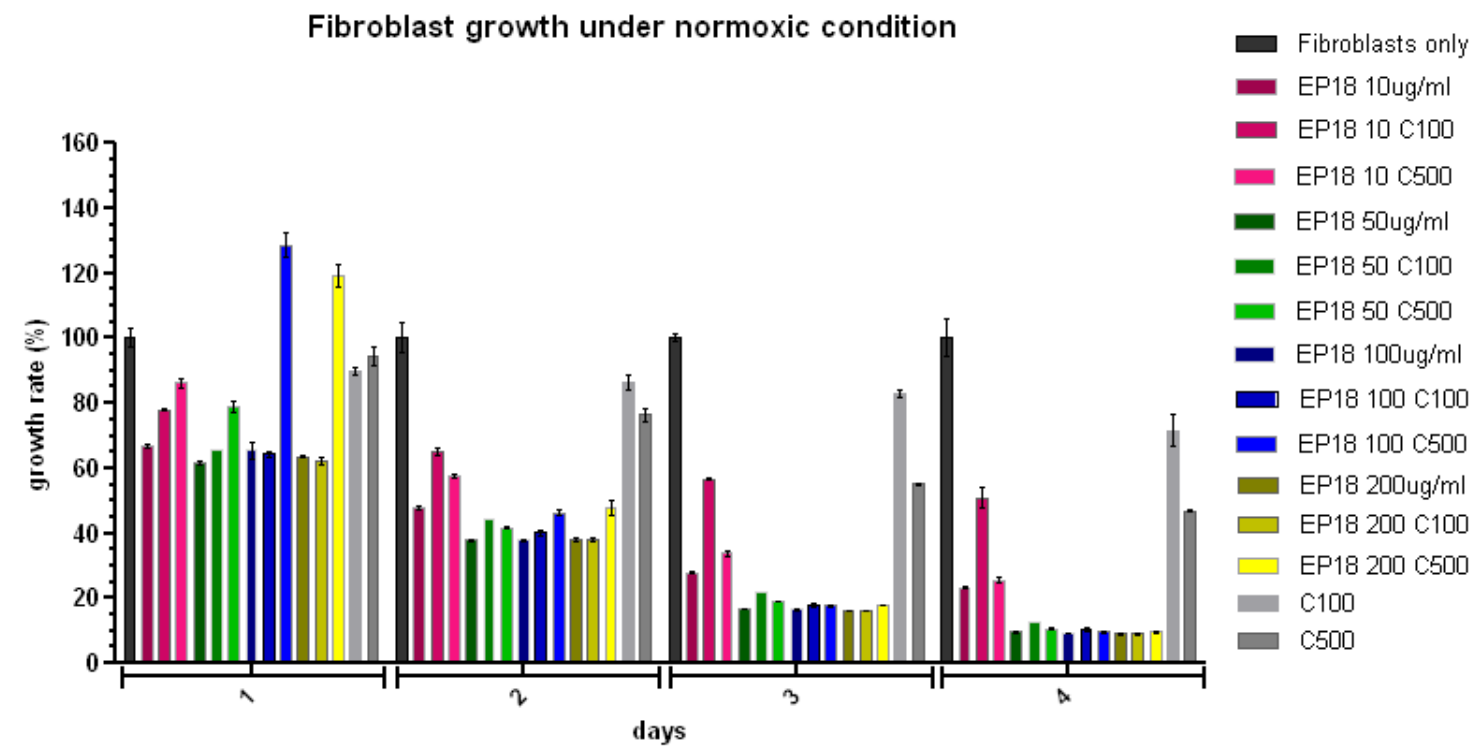

Fibroblasts grown under normoxic conditions over 4 days. The growth rate without additives (black bars) was normalized to $100 \%$. Addition of different concentrations of endoperoxide 18 (EP18) without or with vitamin C (C). The colors indicate one set of experiments at one fixed concentration of 18 (EP18). Vitamin C alone (grey bars) served as control. In general, all additives were detrimental for cell growth except high concentrations on vitamin $\mathrm{C}$ and $\mathbf{1 8}$ (blue bars, only on the first day). Read legend as follows: EP18 10 C500, endoperoxide 18 at 10 $\mu \mathrm{g} / \mathrm{mL}+500 \mu \mathrm{g} / \mathrm{mL}$ vitamin $\mathrm{C}$. 
Graph 3. Normalized growth rate of Fibroblasts under anoxic conditions

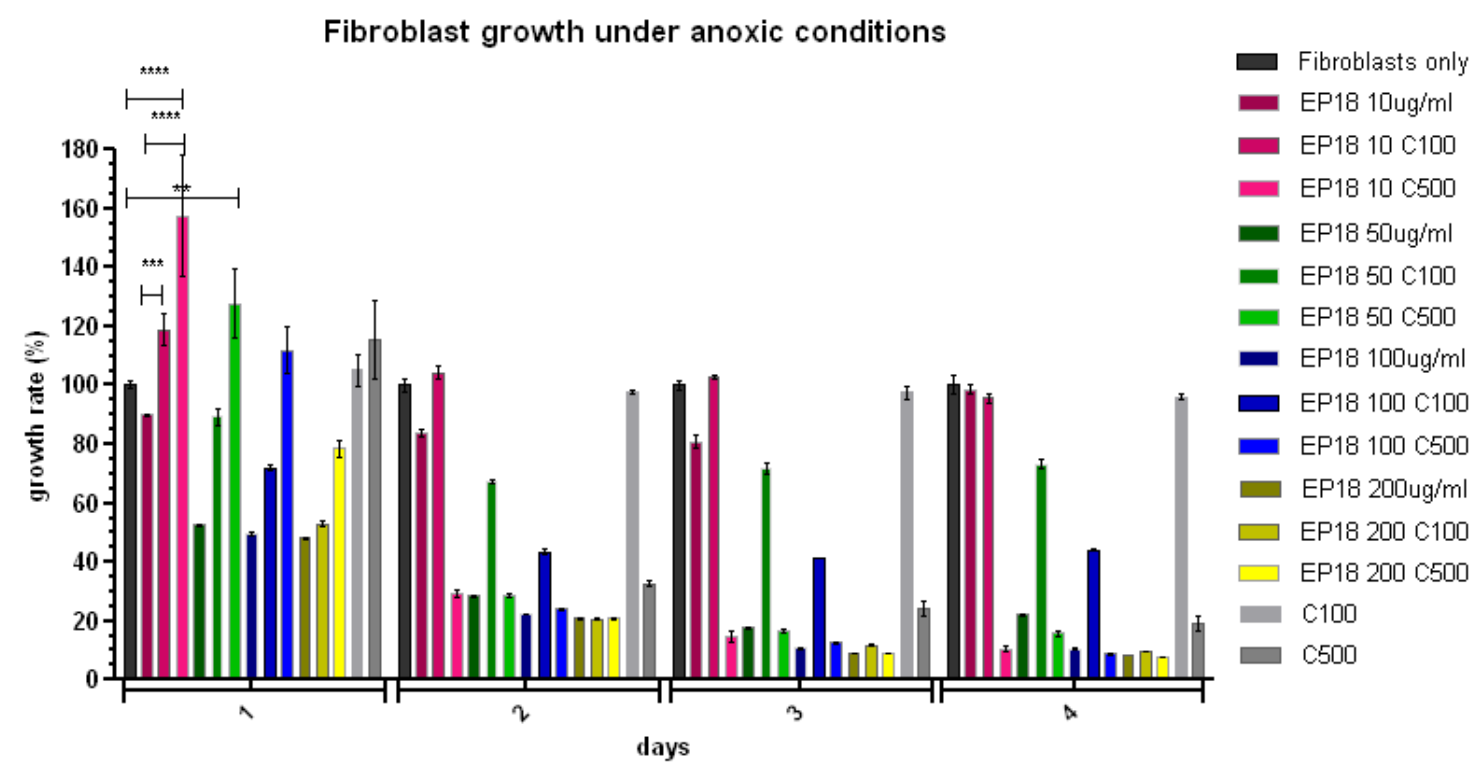

Fibroblasts grown under anoxic conditions over 4 days. The growth rate without additives was normalized to $100 \%$. Addition of different concentrations of endoperoxide 18 (EP18) without or with vitamin $\mathrm{C}(\mathrm{C})$. The colors indicate one set of experiments at one fixed concentration of $\mathbf{1 8}$ (EP18). Vitamin C alone (grey bars) served as control. Addition of vitamin C (100 $\mu \mathrm{g} / \mathrm{mL})$ reduced cytotoxicity of $\mathbf{1 8}$ and a significant effect on cell growth was observed on day 1 (red bars). For the following days 2-4 cell growth was reduced to normal levels again. Read legend as follows: EP18 10 C500, endoperoxide 18 at $10 \mu \mathrm{g} / \mathrm{mL}+500 \mu \mathrm{g} / \mathrm{mL}$ vitamin C.

Next, it was important to find out the optimal concentration range of the endoperoxide $\mathbf{1 8}$ in the presence of vitamin C. $100 \mu \mathrm{g} / \mathrm{mL} \mathbf{1 8}$ were still found to reduce cell viability by a factor of ca. 10 in FBs in the presence of vitamin C under normoxic conditions (Graph 2, blue bars, day 4), whereas under anoxic conditions the viability was only impaired by a factor of 2 (Graph 3, blue bars, day 4). If $200 \mu \mathrm{g} / \mathrm{mL} \mathbf{1 8}$ were used, no beneficial effect of vitamin C could be observed anymore (Graph 2 and 3, yellow bars). The cytotoxicity of $\mathbf{1 8}$ at $50 \mu \mathrm{g} / \mathrm{mL}$ was still considerable even in the presence of vitamin C (Graph 2 and 3, green bars). The best results were obtained with $10 \mu \mathrm{g} / \mathrm{mL}$ of endoperoxide $\mathbf{1 8}$ in the presence of $100 \mu \mathrm{g} / \mathrm{mL}$ vitamin C (Graph 2 and 3 , red bars). 
Under anoxic conditions the combination of endoperoxide $\mathbf{1 8}(10 \mu \mathrm{g} / \mathrm{mL})$ with vitamin C (100 $\mu \mathrm{g} / \mathrm{mL}$ ) displayed no cytotoxicity in FBs but a significant beneficial effect on day 1 (graph 3, red bars).

For SMCs, a similar picture was obtained. Under normoxic conditions SMC growth rate was impaired starting from a concentration of $50 \mu \mathrm{g} / \mathrm{mL}$ endoperoxide $\mathbf{1 8}$. This cytotoxicity of $\mathbf{1 8}$ was much less pronounced in SMCs as compared to FBs. Vitamin C alone (100 and $200 \mu \mathrm{g} /$ $\mathrm{mL}$ ) had neither a beneficial nor detrimental effect on cell growth (graph 4, grey bars) but enhanced cell survival in the presence of endoperoxide $\mathbf{1 8}$ at $50 \mu \mathrm{g} / \mathrm{mL}$ (graph 4, green bars). As a control, the parent pyridone $\mathbf{1 2}$ that is also released in the retro Diels-Alder reaction did not show a beneficial effect on cell growth (graph 4, orange bars).

Strikingly, SMCs showed increased cell growth under anoxic conditions even over 4 days in the presence of endoperoxide $\mathbf{1 8}(10 \mu \mathrm{g} / \mathrm{mL})$ and vitamin $\mathrm{C}(100 \mu \mathrm{g} / \mathrm{mL})$ as compared to the control experiment and normoxic conditions (graph 5, red bars, shown in more detail in graph 6). Endoperoxide $\mathbf{1 8}$ alone did not have this significant effect, likely counterbalancing the cytotoxicity of singlet oxygen. Also at $50 \mu \mathrm{g} / \mathrm{mL} 18$ the beneficial effect of $\mathrm{O}_{2}$ release was counterbalanced by the cytotoxicity at this concentration, which is also valid for high amounts of vitamin C (200 $\mu \mathrm{g} / \mathrm{mL})$. Pyridone $12(50 \mu \mathrm{g} / \mathrm{mL})$ in the presence of vitamin C did not increase cell survival over four days significantly (graph 5, orange bars) and was nontoxic up to concentrations of $100 \mu \mathrm{g} / \mathrm{mL}$ if tested alone (data not shown).

In summary, pyridone endoperoxide $\mathbf{1 8}$ in the presence of vitamin C can supply cells under anoxic conditions with $\mathrm{O}_{2}$ and increase survival over extended periods of time. 
Graph 4. Normalized growth rate of smooth muscle cells under normoxic conditions

\section{Smooth muscle cell growth under normoxic condition}

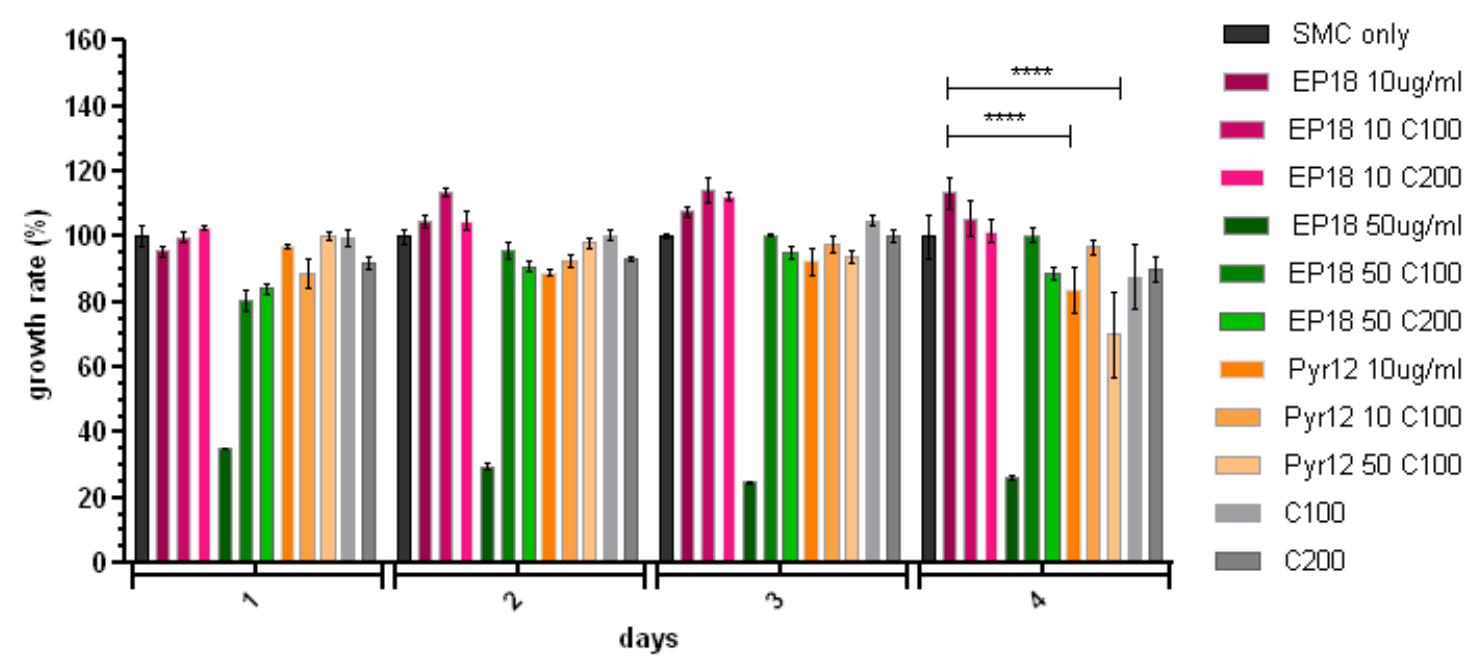

Smooth muscle cells grown under normoxic conditions over 4 days. The growth rate without additives was normalized to $100 \%$. Addition of two different concentrations of endoperoxide $\mathbf{1 8}$ (EP18) without or with vitamin C. The colors indicate one set of experiments at one fixed concentration of 18 (EP18). Vitamin C (C) alone (grey bars) served as control. Pyridone 12 at 10 $\mu \mathrm{g} / \mathrm{mL}$ (Pyr12) served as a negative control (orange bars) and had no beneficial effect on cell growth in the presence or absence of vitamin C (C). Read legend as follows: EP18 10 C100, endoperoxide 18 at $10 \mu \mathrm{g} / \mathrm{mL}+100 \mu \mathrm{g} / \mathrm{mL}$ vitamin C. 
Graph 5. Normalized growth rate of smooth muscle cells under anoxic conditions

Smooth muscle cell growth under anoxic condition

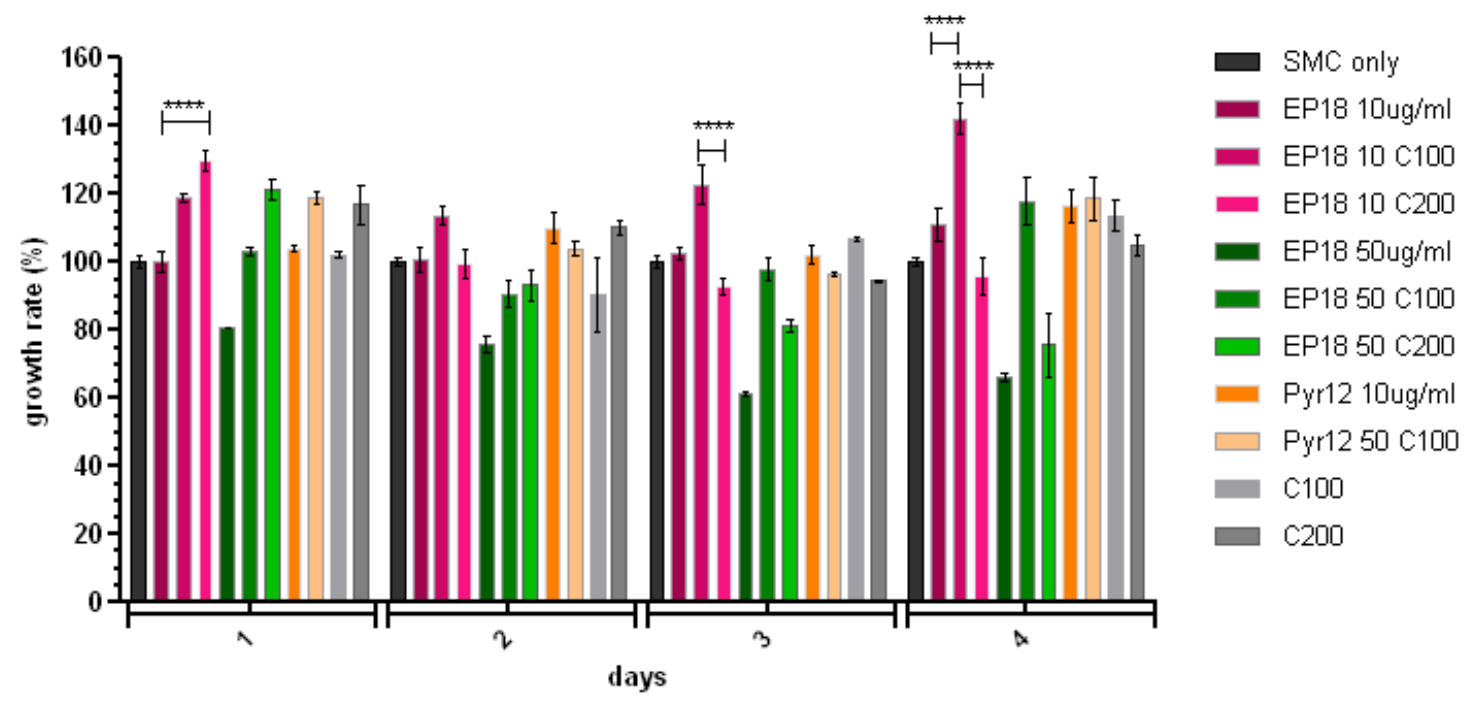

Smooth muscle cells grown under anoxic conditions over 4 days. The growth rate without additives was normalized to $100 \%$. Addition of different concentrations of endoperoxide $\mathbf{1 8}$ (EP18) without or with vitamin C (C). The colors indicate one set of experiments at one fixed concentration of 18 (EP18). Vitamin C alone (grey bars) served as control. Addition of vitamin C $(100 \mu \mathrm{g} / \mathrm{mL})$ and 18 resulted in a significant effect on cell growth over 4 days (dark red bars). Pyridone 12 (Pyr12) served as a negative control. Read legend as follows: EP18 10 C100, endoperoxide 18 at $10 \mu \mathrm{g} / \mathrm{mL}+100 \mu \mathrm{g} / \mathrm{mL}$ vitamin $\mathrm{C}$. 
Graph 6. Normalized growth rate of smooth muscle cells under anoxic conditions

\section{SMC with endoperoxide $18+$ Vit. $C$ under anoxic conditions}

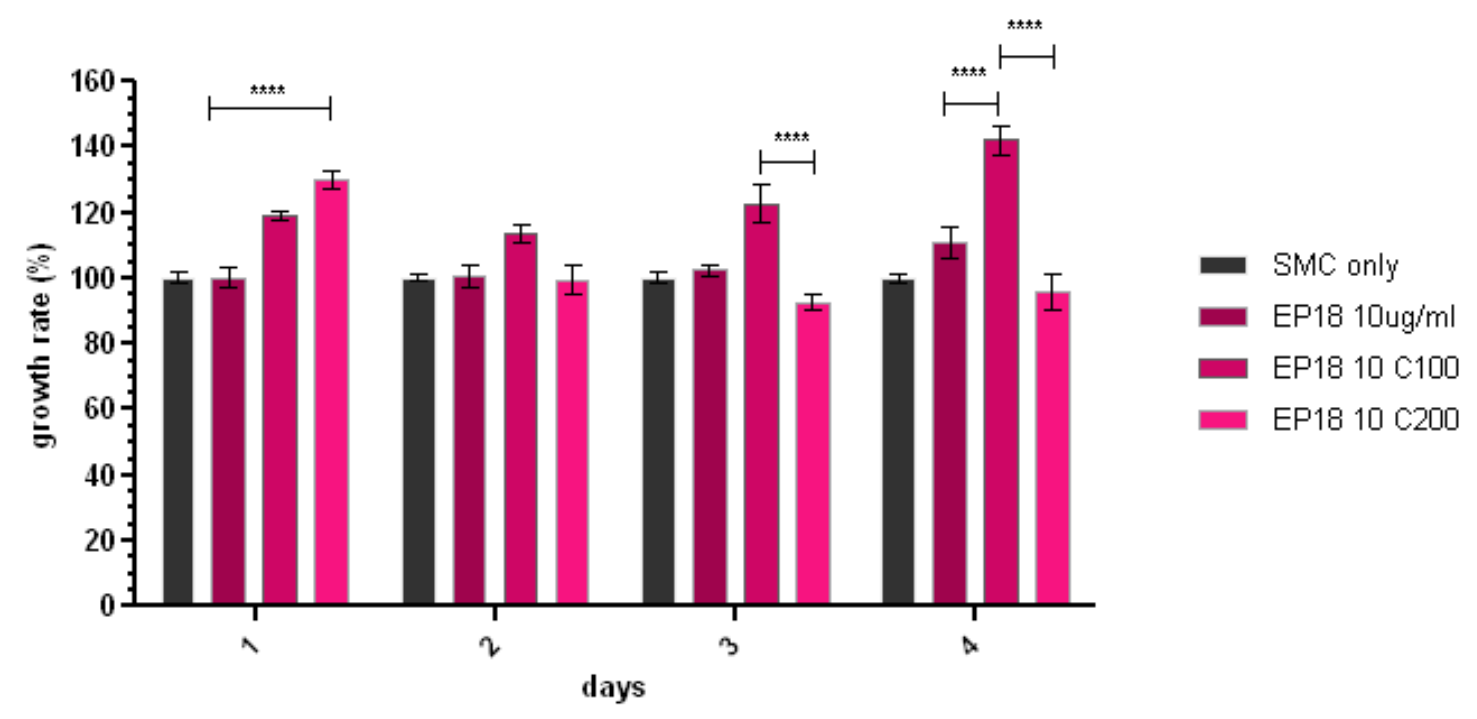

Smooth muscle cells grown under anoxic conditions over 4 days. A clear beneficial effect of endoperoxide 18 (EP18) on growth rate in the presence of vitamin C (100 $\mu \mathrm{g} / \mathrm{mL})$ was observed over 4 days. Read legend as follows: EP18 10 C100, endoperoxide 18 at $10 \mu \mathrm{g} / \mathrm{mL}+100 \mu \mathrm{g} / \mathrm{mL}$ vitamin $\mathrm{C}$.

${ }^{1} \mathrm{O}_{2}$ release. Given a molar volume of $24 \mathrm{~L} / \mathrm{mol}$ at $25^{\circ} \mathrm{C}$ of $\mathrm{O}_{2}$, in principle an $80 \%$ retro Diels Alder reaction of $10 \mu \mathrm{g}$ endoperoxide $\mathbf{1 8}$ can release $600 \mathrm{~nL}$ of oxygen. To further support the idea of initial singlet oxygen release from the pyridone endoperoxide 18, the singlet oxygen sensor green ${ }^{\circledR}$ assay from Invitrogen was applied. Briefly, a singlet oxygen responsive moiety attached to a fluorophore and quenching its fluorescence is the basis of this assay. After reaction of the responsive moiety with singlet oxygen, the emission of the fluorophore is restored, allowing fluorimetric readout. ${ }^{59}$ Graph 7 shows the results of the experiments conducted in the presence and absence of vitamin C. From the data it becomes obvious, that pyridone endoperoxide 18 releases singlet oxygen and that addition of vitamin $\mathrm{C}$ efficiently quenches the released singlet oxygen. 
Graph 7. SOSG assay ${ }^{\circledR}$ to detect singlet oxygen released from endoperoxide 18

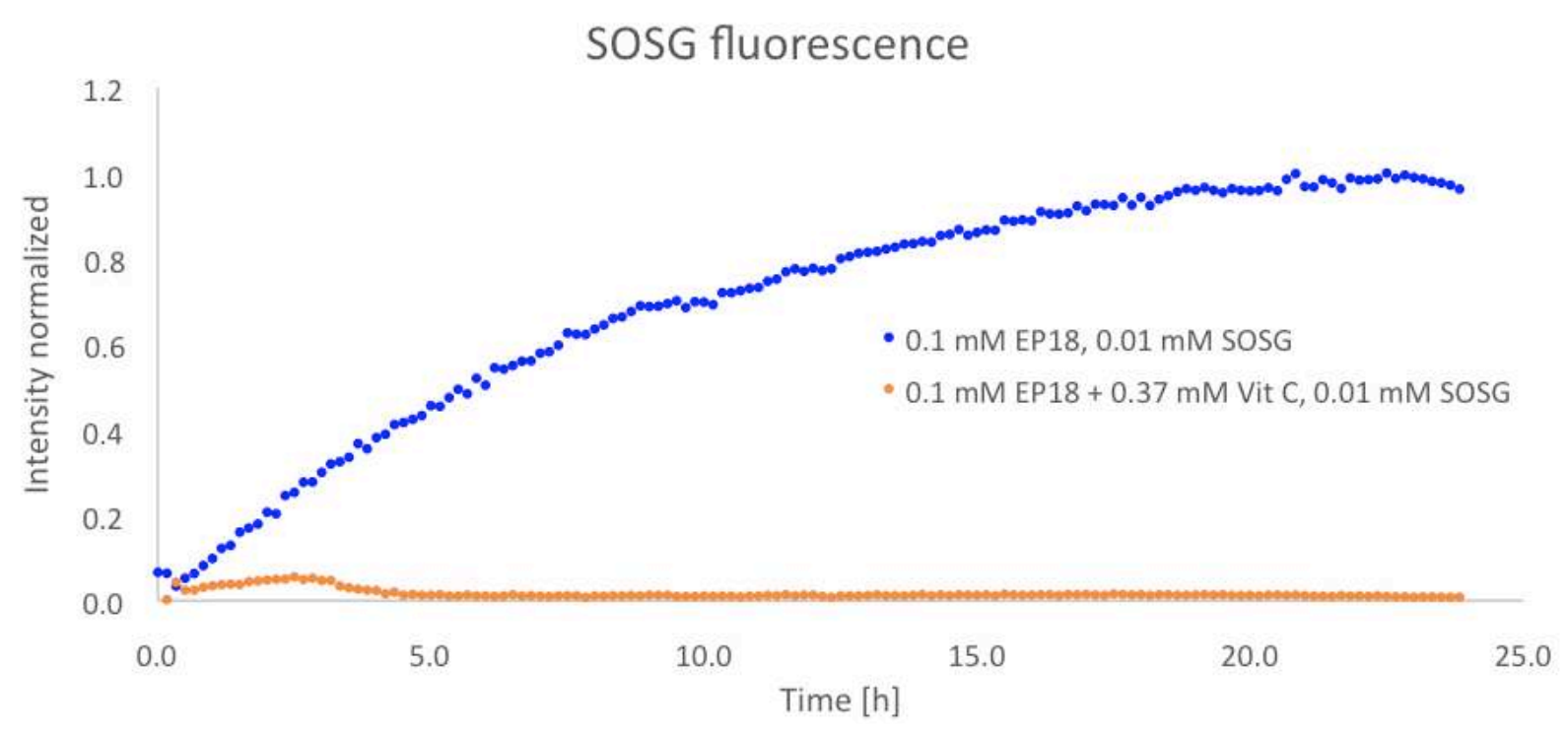

Singlet oxygen sensor green ${ }^{\circledR}$ (SOSG) detects singlet oxygen released from pyridone endoperoxide 18 (EP18) in water at $37{ }^{\circ} \mathrm{C}$ (blue dots). Fluorescence was monitored with the exitation/emission pair $488 / 525 \mathrm{~nm}$. In the presence of vitamin C, no singlet oxygen is detected anymore (orange dots).

CONCLUSION. While in many studies involving oxygen generation cytotoxicity of a compound is the ultimate goal, as e.g. in cancer research, ${ }^{60,61}$ the support of damaged tissue with small organic molecules is a largely unexplored area. In tissue engineering, survival of the grafts is critical and failure in sufficient oxygen supply can lead to necrosis. Usually, poor vascularization is one severe problem in larger grafts. Hypoxic conditions are generally well tolerated by cells as reduced oxygen pressure can be found in most tissues. However, anoxic conditions can have devastating effects on cell survival. Thus, it is likely that already minute amounts of oxygen can rescue anoxic tissue from necrosis. Moreover, fibroblasts entering hypoxic tissue have increased amounts of mRNA encoding vascular endothelial growth factor (VEGF) an important signaling protein in vasculogenesis and angiogenesis. 
In this study, fibroblasts and smooth muscle cells were grown under normoxic $\left(21 \% \mathrm{O}_{2}\right)$ and anoxic $\left(0 \% \mathrm{O}_{2}\right)$ conditions in the presence of water-soluble pyridone endoperoxides. The endoperoxide used in the assays was optimized towards long half-life in water ( $8 \mathrm{~h}$ to $13 \mathrm{~h}$ ) and efficient retro Diels Alder reaction (ca. 80\%), releasing (singlet) oxygen. The cytotoxicity of the released singlet oxygen was controlled by addition of vitamin C. Efficient quenching of singlet oxygen by vitamin $\mathrm{C}$ was demonstrated by applying the singlet oxygen sensor green assay. The cell studies clearly show a reduction of the cytotoxicity of endoperoxides in the presence of vitamin C. Moreover, FBs showed increased growth rate under anoxic conditions on the first day of the study and SMCs had increased growth rates over 4 days as compared to the controls. Thus, pyridone endoperoxides efficiently release oxygen under cell culture conditions and can rescue cell growth under strictly anoxic conditions in two important cell lines responsible for early vascularization. It should be possible to covalently attach these molecules to polymeric scaffolds, thus enabling the generation of oxygen releasing polymers that can be used in tissue engineering. The endoperoxides, either in free form or attached to bandages could in principle be used to support necrotic wounds with oxygen. The efficiency in the latter process will be studied in a mouse skin flap model in due course.

\section{EXPERIMENTAL SECTION.}

Synthesis. Chemicals were purchased from commercial suppliers (Acros, Aldrich, TCI) and used without further purification, unless noted otherwise. Deuterated solvents were obtained from Armar Chemicals, Switzerland, in the indicated purity grade. ${ }^{1} \mathrm{H}$ NMR spectra were recorded on Bruker 300 \& $400 \mathrm{MHz}$ spectrometers, Bruker $500 \mathrm{MHz}$ spectrometers (equipped with a cryo platform) at $298 \mathrm{~K}$ in the indicated deuterated solvent. Data are reported as follow: chemical shift 
$(\delta$, ppm), multiplicity (s, singulet; $d$, doublet; $t$, triplet; q, quartet; $\mathrm{m}$, multiplet or not resolved signal; br, broad signal), coupling constant(s) $(J, \mathrm{~Hz})$, integration. All signals were referenced to the internal solvent signal as standard $\left(\mathrm{CDCl}_{3}, \delta 7.26 ; \mathrm{D}_{2} \mathrm{O}, \delta 4.79 ; \mathrm{CD}_{3} \mathrm{OD}, \delta 3.31 ; \mathrm{DMSO}_{6}, \delta\right.$ 2.50). ${ }^{13} \mathrm{C}$-NMR spectra were recorded with ${ }^{1} \mathrm{H}$-decoupling on Bruker $75,101 \mathrm{MHz}$ or Bruker $125 \mathrm{MHz}$ spectrometers (equipped with a cryo platform) at $298 \mathrm{~K}$ in the indicated deuterated solvent. All signals were referenced to the internal solvent signal as standard $\left(\mathrm{CDCl}_{3}, \delta 77.16\right.$, $\left.\mathrm{CD}_{3} \mathrm{OD}, \delta 49.0 ; \mathrm{DMSO}_{6}, \delta 39.5\right)$. IR Spectra were recorded on a JASCO FT-IR-4100 spectrometer and data are reported in terms of frequency of absorption $\left(\mathrm{cm}^{-1}\right)$. Microwave experiments were conducted on a CEM Discover microwave (300 Watt, $10 \mathrm{~mL}$ Tube volume).

Mass spectra were recorded by the Mass spectroscopy Service of UZH on Finnigan MAT95 MS, Bruker EsquireLC MS , Bruker maXis QTof HR MS and Finnigan TSQ700 MS machines. For thin layer chromatography (TLC) Merck precoated $60 \mathrm{~F}_{254}$ plates with a $0.2 \mathrm{~mm}$ layer of silica gel were used. For column chromatography, Merck silica gel 60, 230-400 mesh was used. The purity of the compounds was additionally checked by HPLC analysis (CN modified silica, elution with hexane/iprOH gradient) and found to be $>95 \%$ unless indicated otherwise.

Fluorescence Measurements. One vial of singlet oxygen sensor green ${ }^{\circledR}$ (Invitrogen), was dissolved in $33 \mu \mathrm{L} \mathrm{MeOH}$. The endoperoxide was dissolved in $10 \mu \mathrm{L} \mathrm{MeOH}$ and diluted with water to the desired concentrations. Vitamin C was dissolved only in water. $200 \mu \mathrm{L}$ of total volume was introduced into a black 96-well plate (Greiner Bio One) and covered with a transparent plastic foil. The plate was placed into a plate reader (Spectra Max M5, Molecular Devices) and every 10 minutes a value was recorded at $37{ }^{\circ} \mathrm{C}$ (excitation/emission 488/525 nm). 
All measurements were conducted in triplicate. Blank measurements containing SOSG and SOSG/vitamin C were subtracted from the results.

6-Methyl-2-pyridone 2. 2-Bromo-6-methylpyridine 1 ( $500 \mathrm{mg}, 2.90 \mathrm{mmol})$ and freshly prepared sodium methoxide $(313 \mathrm{mg}, 5.80 \mathrm{mmol})$ were dissolved in $\mathrm{MeOH}(4 \mathrm{~mL})$ and heated in the microwave for $1 \mathrm{~h}$ at $105^{\circ} \mathrm{C}$. The mixture was concentrated under reduced pressure, extracted with diethyl ether and washed with water. The organic layer was concentrated in vacuo. $\mathrm{HCl}$ $32 \%(1.5 \mathrm{~mL})$ and 1,4-dioxane $(2 \mathrm{~mL})$ were added and the solution heated in the microwave for $2 \mathrm{~h}$ at $100{ }^{\circ} \mathrm{C}$. The reaction mixture was concentrated in vacuo, dissolved in DCM and washed with water. The organic layer was dried with $\mathrm{MgSO}_{4}$ and concentrated to yield the title compound as a colorless solid (220 mg, $2.02 \mathrm{mmol}, 70 \%)$.

${ }^{1} \mathrm{H}$ NMR $\left(400 \mathrm{MHz}, \mathrm{CDCl}_{3}\right) \delta$ 13.57-12.19 (bs, 1H), $7.38(\mathrm{dd}, J=9.1,6.9 \mathrm{~Hz}, 1 \mathrm{H}), 6.43(\mathrm{~d}, J=$ $9.1 \mathrm{~Hz}, 1 \mathrm{H}), 6.09(\mathrm{~d}, J=6.9 \mathrm{~Hz}, 1 \mathrm{H}), 2.37(\mathrm{~s}, 3 \mathrm{H}) ;{ }^{13} \mathrm{C} \mathrm{NMR}\left(126 \mathrm{MHz}, \mathrm{CDCl}_{3}\right) \delta$ 166.2, 146.1, 142.1, 116.5, 106.2, 19.1; HRMS (ESI) calcd for $\mathrm{C}_{6} \mathrm{H}_{7} \mathrm{NNaO}[\mathrm{M}]^{+} 132.04198$, found 132.04192.

2,5-Dibromo-3,6-dimethylpyridine. Oleum (20\% in water, $20 \mathrm{~mL}$ ) was cooled to $0{ }^{\circ} \mathrm{C}$ and 2,5 lutidine $3(1.50 \mathrm{~g}, 14.0 \mathrm{mmol})$ was added slowly. After warming to room temperature, TBCA $(5.12 \mathrm{~g}, 14.0 \mathrm{mmol})$ was added in $1 \mathrm{~g}$ portions over a period of $2.5 \mathrm{~h}$ to the stirred solution. The reaction mixture was poured on ice water $(80 \mathrm{~mL})$, neutralized with sodium carbonate and extracted with diethylether. The organic layer was dried over magnesium sulfate and evaporated to give the title compound as a colorless solid $(3.30 \mathrm{~g}, 12.5 \mathrm{mmol}, 89 \%)$. This material was used in the next step without further purification.

${ }^{1} \mathrm{H}$ NMR $\left(300 \mathrm{MHz}, \mathrm{CDCl}_{3}\right) \delta 7.62(\mathrm{~s}, 1 \mathrm{H}), 2.60(\mathrm{~s}, 3 \mathrm{H}), 2.33(\mathrm{~s}, 3 \mathrm{H}) ;{ }^{13} \mathrm{C}$ NMR $(126 \mathrm{MHz}$ $\left.\mathrm{CDCl}_{3}\right) \delta 155.6,142.1,142.0,134.1,120.2,24.1,21.3$; HRMS (ESI) calcd for $\mathrm{C}_{7} \mathrm{H}_{7} \mathrm{Br}_{2} \mathrm{~N}[\mathrm{M}]^{+}$ 263.90180, found 263.90167 . 
3-Bromo-2-methoxy-3,6-dimethylpyridine 4. 2,5-Dibromo-3,6-dimethylpyridine (3.00 g, 11.3 mmol) was added to freshly prepared sodium methoxide $(2.45 \mathrm{~g}, 45.3 \mathrm{mmol})$ in $\mathrm{MeOH}(12 \mathrm{~mL})$, devided in to three equal portions and irradiated in the microwave at $100^{\circ} \mathrm{C}$ for $1 \mathrm{~h}$. The mixtures were combined, concentrated in vacuo and redissolved in EtOAc and water. The organic layer was washed with brine, dried over magnesium sulfate and concentrated in vacuo. The residue was diluted with hexane and a white solid was filtered off. The filtrate was concentrated to give the product as a clear liquid $(2.10 \mathrm{~g}, 9.72 \mathrm{mmol}, 89 \%)$. The product was used in the next step without further purification.

${ }^{1} \mathrm{H}$ NMR (400 MHz, $\left.\mathrm{CDCl}_{3}\right) \delta 7.44$ (s, 1H), 3.91 (s, 3H), 2.50 (s, 3H), 2.12 (s, 3H); ${ }^{13} \mathrm{C}$ NMR $\left(126 \mathrm{MHz}, \mathrm{CDCl}_{3}\right) \delta 160.7,151.1,141.7,119.9,111.4,53.6,24.0,15.3 ; \mathrm{IR} v_{\max } / \mathrm{cm}^{-1} 2948,1569$, 1459, 1356, 1313, 1246, 1174, 1036, 962; HRMS (ESI) calcd for $\mathrm{C}_{8} \mathrm{H}_{11} \mathrm{BrNO}[\mathrm{M}]^{+} 216.00185$, found 216.00168

3,6-Dimethyl-2-pyridone 5. Pyridine 4 (700 mg, $3.23 \mathrm{mmol})$ was dissolved in $10 \mathrm{~mL}$ dry THF and cooled to $-78^{\circ} \mathrm{C}$. To this solution was slowly added $n$-BuLi $(2.5 \mathrm{M}$ in hexane, $1.43 \mathrm{~mL}, 3.56$ mmol) and after stirring for $2.5 \mathrm{~h}$ the mixture was warmed to $0{ }^{\circ} \mathrm{C}$ and $\mathrm{H}_{2} \mathrm{O}(1.5 \mathrm{~mL})$ was added carefully. The solution was concentrated in vacuo. $\mathrm{HCl} 32 \%(2.5 \mathrm{~mL})$ and 1,4-dioxane $(2 \mathrm{~mL})$ were added and the solution heated in the microwave at $100{ }^{\circ} \mathrm{C}$ for $2 \mathrm{~h}$. The mixture was neutralized with sodium carbonate and extracted with ethyl acetate, washed with brine and concentrated in vacuo. Purification by flash chromatography (9:1 DCM/MeOH v/v) yielded the title compound as a colorless solid (270 mg, $2.19 \mathrm{mmol}, 68 \%)$.

Melting point $173-175^{\circ} \mathrm{C} ;{ }^{1} \mathrm{H}$ NMR $\left(500 \mathrm{MHz}, \mathrm{CDCl}_{3}\right) \delta 12.90-12.26$ (bs, $\left.1 \mathrm{H}\right), 7.19(\mathrm{~d}, J=6.9$ $\mathrm{Hz}, 1 \mathrm{H}), 5.95(\mathrm{~d}, J=6.9 \mathrm{~Hz}, 1 \mathrm{H}), 2.32(\mathrm{~s}, 3 \mathrm{H}), 2.11(\mathrm{~s}, 3 \mathrm{H}) ;{ }^{13} \mathrm{C}$ NMR $\left(126 \mathrm{MHz}, \mathrm{CDCl}_{3}\right) \delta$ 
165.7, 142.7, 139.4, 125.4, 105.7, 18.9, 16.3; IR $v_{\max } / \mathrm{cm}^{-1} 2924,1642,1580,1480,593$; HRMS (ESI) calcd for $\mathrm{C}_{7} \mathrm{H}_{9} \mathrm{NNaO}[\mathrm{M}+\mathrm{Na}]^{+} 146.05764$, found 146.05776 .

3,5,6-Trimethyl-2-pyridone 6. Pyridine 4 (700 mg, $3.23 \mathrm{mmol})$ was dissolved in $10 \mathrm{~mL}$ dry THF and cooled to $-78{ }^{\circ} \mathrm{C}$. To this solution was slowly added $n$-BuLi $(2.5 \mathrm{M}$ in hexane, $1.43 \mathrm{~mL}$, $3.56 \mathrm{mmol})$. After stirring for $2.5 \mathrm{~h}$, methyl iodide $(1.38 \mathrm{~g}, 9.73 \mathrm{mmol})$ was added and the mixture was warmed to room temperature. The solution was stirred for 50 min, concentrated in vacuo and dissolved in $\mathrm{HCl} 32 \%(1.5 \mathrm{~mL})$ and 1,4-dioxane $(2 \mathrm{~mL})$. The mixture was heated in the microwave for $1.5 \mathrm{~h}$ at $100{ }^{\circ} \mathrm{C}$, concentrated in vacuo and extracted with DCM. The organic layer was washed with sat. sodium carbonate, sat. ammonium chloride, $1 \mathrm{M}$ sodium thiosulfate and brine. The organic layer was dried over $\mathrm{MgSO}_{4}$ and concentrated in vacuo. Purification by flash chromatography $(9: 1 \mathrm{DCM} / \mathrm{MeOH} \mathrm{v} / \mathrm{v})$ yielded the title compound as an off-white solid (310 mg, $2.26 \mathrm{mmol}, 70 \%)$.

${ }^{1} \mathrm{H}$ NMR (400 MHz, $\mathrm{CDCl}_{3}$ ) $\delta$ 12.7-11.28 (bs, 1H), 7.12 (s, 1H), 2.26 (s, 3H), 2.11 (s, 3H), 2.02 $(\mathrm{s}, 3 \mathrm{H}) ;{ }^{13} \mathrm{C}$ NMR $\left(126 \mathrm{MHz}, \mathrm{CDCl}_{3}\right) \delta 164.9,142.7,139.1,125.0,112.5,16.7,16.2,16.1$; HRMS (ESI) calcd for $\mathrm{C}_{8} \mathrm{H}_{12} \mathrm{NO}[\mathrm{M}]^{+} 138.09134$, found 138.09143 .

3,5-Dimethylpyridine- $N$-oxide. 3,5-Dimethylpyridine 7 (3.00 g, $28.0 \mathrm{mmol})$ was dissolved in $\operatorname{DCM}(50 \mathrm{~mL})$ and cooled to $0{ }^{\circ} \mathrm{C} . \mathrm{mCPBA}(75 \%$ stabilized with water, $7.00 \mathrm{~g}, 30.8 \mathrm{mmol})$ was added in 3 portions over a period of $10 \mathrm{~min}$. The solution was warmed to room temperature, stirred for $5 \mathrm{~h}$. The organic layer was mixed with sat. $\mathrm{NaHCO}_{3}$ and extracted four times with DCM. The combined organic layers were dried over $\mathrm{MgSO}_{4}$ and concentrated in vacuo to yield the product as a colorless solid $(2.10 \mathrm{~g}, 17.0 \mathrm{mmol}, 61 \%)$. 
${ }^{1} \mathrm{H}$ NMR (300 MHz, $\left.\mathrm{CDCl}_{3}\right) \delta 7.95$ (s, 2H), 6.95 (s, 1H), 2.27 (s, 6H); ${ }^{13} \mathrm{C} \mathrm{NMR} \mathrm{(126} \mathrm{MHz,}$ $\left.\mathrm{CDCl}_{3}\right) \delta 136.5,136.0,129.0,18.1$; HRMS (ESI) calcd for $\mathrm{C}_{7} \mathrm{H}_{10} \mathrm{NO}[\mathrm{M}]^{+}$124.07569, found 124.07562.

3,5-Dimethyl-2-pyridone 8. 3,5-Dimethylpyridine- $N$-oxide (2.10 g, $17.0 \mathrm{mmol})$ was dissolved in acetic acid anhydride $(30 \mathrm{ml})$ and heated under reflux for $20 \mathrm{~h}$. The solution was concentrated in vacuo. Water $(25 \mathrm{~mL})$ was added and the resulting mixture was heated under reflux for $2 \mathrm{~h}$. The mixture was concentrated in vacuo and dried by repeated azeotropic distilliation with toluene. Purification by flash chromatography $(9: 1 \mathrm{DCM} / \mathrm{MeOH} \mathrm{v} / \mathrm{v})$ yielded the title compound as an off-white solid $(0.80 \mathrm{~g}, 6.5 \mathrm{mmol}, 38 \%)$.

Melting point $86-89{ }^{\circ} \mathrm{C} ;{ }^{1} \mathrm{H}$ NMR $\left(300 \mathrm{MHz}, \mathrm{CDCl}_{3}\right) \delta 12.67-11.95$ (bs, $\left.1 \mathrm{H}\right), 7.19(\mathrm{~d}, J=1.1 \mathrm{~Hz}$, 1H), $7.04(\mathrm{~s}, 1 \mathrm{H}), 2.15(\mathrm{~s}, 3 \mathrm{H}), 2.06(\mathrm{~d}, J=0.8 \mathrm{~Hz}, 3 \mathrm{H}) ;{ }^{13} \mathrm{C} \mathrm{NMR}\left(126 \mathrm{MHz}, \mathrm{CDCl}_{3}\right) \delta 164.6$, $142.0,129.6,128.5,115.9,17.1,16.7 ; \mathrm{IR} v_{\max } / \mathrm{cm}^{-1} 3390,1656,1630,1563,1472,1375,964$, 881, 701; HRMS (ESI) calcd for $\mathrm{C}_{7} \mathrm{H}_{10} \mathrm{NO}[\mathrm{M}]^{+}$124.07569, found 124.07569.

2-[2-(2-Methoxyethoxy)ethoxy]ethyl 2-bromoacetate. ${ }^{41}$ Bromoacetic acid $(5.00 \mathrm{~g}, 36.0 \mathrm{mmol})$, triethylenglycol monomethylether $(5.61 \mathrm{~g}, 34.2 \mathrm{mmol})$ and a catalytic amount dimethylaminopyridine (DMAP, $50 \mathrm{mg}$ ) were dissolved in DCM $(200 \mathrm{~mL})$ and cooled to $0{ }^{\circ} \mathrm{C}$. Dicyclohexylcarbodiimide (DCC, $8.17 \mathrm{~g}, 39.6 \mathrm{mmol}$ ) was slowly added. The mixture was warmed to room temperature and stirred overnight. The white precipitate was filtered off and the filtrate was concentrated in vacuo. The precipitation/filtration process was repeated once more. Purification by flash chromatography $(20: 1 \mathrm{DCM} / \mathrm{MeOH})$ gave the product as a colorless liquid $(5.10 \mathrm{~g}, 52 \%)$.

${ }^{1} \mathrm{H}$ NMR (300 MHz, $\left.\mathrm{CDCl}_{3}\right) \delta 4.31-4.23(\mathrm{~m}, 2 \mathrm{H}), 3.83(\mathrm{~s}, 2 \mathrm{H}), 3.71-3.65(\mathrm{~m}, 2 \mathrm{H}), 3.64-$ $3.54(\mathrm{~m}, 6 \mathrm{H}), 3.53-3.45(\mathrm{~m}, 2 \mathrm{H}), 3.32(\mathrm{~s}, 3 \mathrm{H}) ;{ }^{13} \mathrm{C} \mathrm{NMR}\left(75 \mathrm{MHz}, \mathrm{CDCl}_{3}\right) \delta$ 167.2, 71.9, 70.6, 
70.5, 70.5, 68.7, 65.3, 59.0, 25.8; HRMS (ESI) calcd for $\mathrm{C}_{9} \mathrm{H}_{17} \mathrm{BrNaO}_{5}[\mathrm{M}+\mathrm{Na}]^{+}$307.0152, found 307.0154 .

2-[2-(2-Methoxyethoxy)ethoxy]ethyl 2-(2-oxo-1,2-dihydropyridin-1-yl)acetate 11. 2-pyridone (100 $\mathrm{mg}, 1.05 \mathrm{mmol}$ ) was alkylated according to the same procedure described for product $\mathbf{1 3}$ (see below). Yield: $239 \mathrm{mg}\left(0.798 \mathrm{mmol}, 76 \%\right.$, colorless oil). ${ }^{1} \mathrm{H}$ NMR (400 MHz, $\left.\mathrm{CDCl}_{3}\right) \delta 7.26$ $-7.20(\mathrm{~m}, 1 \mathrm{H}), 7.19-7.13(\mathrm{~m}, 1 \mathrm{H}), 6.41(\mathrm{~d}, J=9.1 \mathrm{~Hz}, 1 \mathrm{H}), 6.06(\mathrm{td}, J=6.7,1.3 \mathrm{~Hz}, 1 \mathrm{H}), 4.55$ (s, 2H), $4.23-4.12(\mathrm{~m}, 2 \mathrm{H}), 3.63-3.53(\mathrm{~m}, 2 \mathrm{H}), 3.53-3.44(\mathrm{~m}, 6 \mathrm{H}), 3.44-3.34(\mathrm{~m}, 2 \mathrm{H}), 3.22$ (s, 3H); ${ }^{13} \mathrm{C}$ NMR $\left(101 \mathrm{MHz}, \mathrm{CDCl}_{3}\right) \delta$ 167.5, 162.1, 140.1, 138.1, 120.4, 105.9, 71.6, 70.3, 70.3, 70.2, 68.5, 64.5, 58.7, 50.1; IR $v_{\max } / \mathrm{cm}-1$ 1748, 1660, 1540,1197, 1097; HRMS (ESI) calculated for $\mathrm{C} 14 \mathrm{H} 21 \mathrm{NNaO6}[\mathrm{M}+\mathrm{Na}]+322.12611$, found 322.12655.

2-[2-(2-Methoxyethoxy)ethoxy]ethyl 2-(3-methyl-2-oxo-1,2-dihydropyridin-1-yl)acetate 12. 3-Methyl-2-pyridone $\mathbf{1 0}$ (200 mg, $1.83 \mathrm{mmol}), \quad$ 2-[2-(2-methoxyethoxy)ethoxy]ethyl 2bromoacetate $(784 \mathrm{mg}, 2.75 \mathrm{mmol})$ and potassium carbonate $(760 \mathrm{mg}, 5.50 \mathrm{mmol})$ were dissolved in DMF $(20 \mathrm{~mL})$ at room temperature and the solution was stirred overnight. The mixture was concentrated in vacuo. The residue was dissolved in ethyl acetate and washed with water. The organic layer was dried over $\mathrm{MgSO}_{4}$ and concentrated in vacuo. Purification by flash chromatography (9:1 DCM/ MeOH v/v) yielded the title compound as a colorless oil (200 mg, $0.64 \mathrm{mmol}, 35 \%)$.

${ }^{1} \mathrm{H}$ NMR $\left(400 \mathrm{MHz}, \mathrm{CDCl}_{3}\right) \delta 7.21-7.16(\mathrm{~m}, 1 \mathrm{H}), 7.11-7.06(\mathrm{~m}, 1 \mathrm{H}), 6.08(\mathrm{t}, J=6.8 \mathrm{~Hz}$, $1 \mathrm{H}), 4.63(\mathrm{~s}, 2 \mathrm{H}), 4.34-4.19(\mathrm{~m}, 2 \mathrm{H}), 3.72-3.45(\mathrm{~m}, 10 \mathrm{H}), 3.33(\mathrm{~s}, 3 \mathrm{H}), 2.10(\mathrm{~s}, 3 \mathrm{H}) ;{ }^{13} \mathrm{C}$ NMR (75 MHz, $\left.\mathrm{CDCl}_{3}\right) \delta$ 168.0, 163.0, 137.5, 135.4, 130.0, 106.0, 72.0, 70.6, 70.6, 70.6, 68.9, 64.8, 59.1, 50.8, 17.2; IR $v_{\text {max }} / \mathrm{cm}^{-1} 1748,1652,1592,1561,1196,1099,768$; HRMS (ESI) calculated for $\mathrm{C}_{15} \mathrm{H}_{23} \mathrm{NNaO}_{6}[\mathrm{M}+\mathrm{Na}]^{+}$336.14176, found 336.14193. 
2-[2-(2-Methoxyethoxy)ethoxy]ethyl 2-(6-methyl-2-oxo-1,2-dihydropyridin-1-yl)acetate 13. 6-Methyl-2-pyridone 2 (50 mg, $0.46 \mathrm{mmol}$ ), dissolved in $10 \mathrm{~mL} \mathrm{DME}$, was cooled to $0{ }^{\circ} \mathrm{C}$ and $\mathrm{NaH}(60 \%$ suspension in oil, $19 \mathrm{mg}, 0.48 \mathrm{mmol})$ was added. After stirring for $10 \mathrm{~min}, \mathrm{LiBr}(80$ $\mathrm{mg}, \quad 0.92 \mathrm{mmol})$ was added and the mixture was stirred for $20 \mathrm{~min}$. 2-[2-(2methoxyethoxy)ethoxy]ethyl 2-bromoacetate $(157 \mathrm{mg}, 0.55 \mathrm{mmol})$ was added. The mixture was heated to $60{ }^{\circ} \mathrm{C}$ for $4 \mathrm{~h}$, cooled to room temperature and filtered. The filtrate was concentrated in vасио. Purification by flash chromatography yielded the desired product as a colorless oil (40 $\mathrm{mg}, 0.13 \mathrm{mmol}, 28 \%)$.

${ }^{1} \mathrm{H}$ NMR $\left(300 \mathrm{MHz}, \mathrm{CDCl}_{3}\right) \delta 7.18(\mathrm{dd}, J=9.2,6.8 \mathrm{~Hz}, 1 \mathrm{H}), 6.38(\mathrm{~d}, J=9.2 \mathrm{~Hz}, 1 \mathrm{H}), 5.98(\mathrm{~d}, J$ $=6.7 \mathrm{~Hz}, 1 \mathrm{H}), 4.77(\mathrm{~s}, 2 \mathrm{H}), 4.33-4.17(\mathrm{~m}, 2 \mathrm{H}), 3.75-3.41(\mathrm{~m}, 10 \mathrm{H}), 3.30(\mathrm{~s}, 3 \mathrm{H}), 2.22(\mathrm{~s}, 3 \mathrm{H})$; ${ }^{13} \mathrm{C}$ NMR $\left(75 \mathrm{MHz}, \mathrm{CDCl}_{3}\right) \delta 167.9,163.3,145.8,139.5,117.4,106.7,71.8,70.5,70.5,70.4$, 68.7, 64.6, 58.9, 45.3, 20.4; IR $v_{\max } / \mathrm{cm}^{-1} 1746,1660,1550,1197,1099,794 ;$ HRMS (ESI) calcd for $\mathrm{C}_{15} \mathrm{H}_{23} \mathrm{NNaO}_{6}[\mathrm{M}+\mathrm{Na}]^{+}$336.1418, found 336.1421.

\section{2-[2-(2-Methoxyethoxy)ethoxy]ethyl 2-(3,5-dimethyl-2-oxo-1,2-dihydropyridin-1-yl)acetate}

14. 3,5-Dimethyl-2-pyridone $8(100 \mathrm{mg}, 0.810 \mathrm{mmol})$ was alkylated according to the same procedure described for product 13. Yield: $132 \mathrm{mg}(0.404,50 \%$, colorless oil).

${ }^{1} \mathrm{H}$ NMR (400 MHz, CDCl3) $\delta 7.08(\mathrm{~d}, \mathrm{~J}=1.1 \mathrm{~Hz}, 1 \mathrm{H}), 6.85(\mathrm{~s}, 1 \mathrm{H}), 4.61(\mathrm{~s}, 2 \mathrm{H}), 4.36-4.24$ $(\mathrm{m}, 2 \mathrm{H}), 3.73-3.67(\mathrm{~m}, 2 \mathrm{H}), 3.66-3.59(\mathrm{~m}, 6 \mathrm{H}), 3.57-3.49(\mathrm{~m}, 2 \mathrm{H}), 3.35(\mathrm{~s}, 3 \mathrm{H}), 2.10(\mathrm{~s}$,

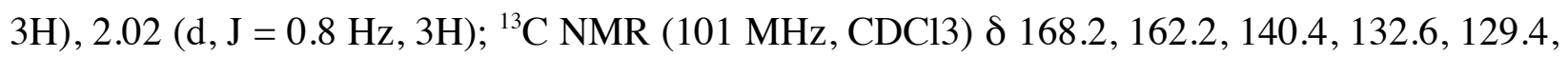
$114.8,72.0,70.7,70.7,70.6,68.9,64.79,59.1,50.7,17.2,17.1 ;$ IR $v_{\max } / \mathrm{cm}^{-1} 1747,1664,1593$, 1195, 1100, 1036; HRMS (ESI) calcd for $\mathrm{C}_{16} \mathrm{H}_{25} \mathrm{NNaO}_{6}[\mathrm{M}+\mathrm{Na}]^{+} 350.1574$, found 350.1579 


\section{2-[2-(2-Methoxyethoxy)ethoxy]ethyl 2-(3,6-dimethyl-2-oxo-1,2-dihydropyridin-1-yl)acetate}

15. 3,6-Dimethyl-2-pyridone 5 (100 mg, $0.81 \mathrm{mmol})$ was dissolved in DME $(9 \mathrm{~mL})$ and cooled to $-20{ }^{\circ} \mathrm{C} . n$ - BuLi $(2.5 \mathrm{M}$ in hexane, $0.36 \mathrm{~mL}, 0.89 \mathrm{mmol}$ ) was slowly added under an argon atmosphere and the solution stirred for $20 \mathrm{~min}$. 2-[2-(2-Methoxyethoxy)ethoxy]ethyl 2bromoacetate $(347 \mathrm{mg}, 1.22 \mathrm{mmol})$ in DME $(0.5 \mathrm{~mL})$ was added, the mixture was warmed to room temperature and stirred over night. Concentration under reduced pressure and purification by flash chromatography $(9: 1 \mathrm{DCM} / \mathrm{MeOH} \mathrm{v} / \mathrm{v})$ yielded the product as a colorless oil (108 $\mathrm{mg}$, $0.33 \mathrm{mmol}, 41 \%)$.

${ }^{1} \mathrm{H}$ NMR $\left(300 \mathrm{MHz}, \mathrm{CDCl}_{3}\right) \delta 7.12(\mathrm{dd}, J=6.9,0.9 \mathrm{~Hz}, 1 \mathrm{H}), 5.98(\mathrm{~d}, J=6.9 \mathrm{~Hz}, 1 \mathrm{H}), 4.84(\mathrm{~s}$, $2 \mathrm{H}), 4.40-4.29(\mathrm{~m}, 2 \mathrm{H}), 3.80-3.49(\mathrm{~m}, 10 \mathrm{H}), 3.38(\mathrm{~s}, 3 \mathrm{H}), 2.26(\mathrm{~s}, 3 \mathrm{H}), 2.11(\mathrm{~s}, 3 \mathrm{H}) ;{ }^{13} \mathrm{C}$ NMR $\left(75 \mathrm{MHz}, \mathrm{CDCl}_{3}\right) \delta 168.3,163.8,142.7,137.0,126.3,106.4,72.0,70.7,70.6,70.6,69.0$, 64.7, 59.1, 45.8, 20.4, 17.1; IR $v_{\max } / \mathrm{cm}^{-1} 1747,1651,1568,1194,1101$; HRMS (ESI) calcd for $\mathrm{C}_{16} \mathrm{H}_{25} \mathrm{NNaO}_{6}[\mathrm{M}+\mathrm{Na}]^{+}$364.1731, found 364.1733.

\section{2-[2-(2-Methoxyethoxy)ethoxy]ethyl}

2-(3,5,6-trimethyl-2-oxo-1,2-dihydropyridin-1-

yl)acetate 16. 3,5,6-Trimethyl-2-pyridone 6 (90 $\mathrm{mg}, 0.66 \mathrm{mmol})$ was dissolved in a mixture of dry DME $(6 \mathrm{~mL})$ and dry DMF $(1.5 \mathrm{~mL})$. Under a nitrogen atmosphere the solution was cooled to $0{ }^{\circ} \mathrm{C}$, sodium hydride ( $60 \%$ in oil, $28 \mathrm{mg}, 0.69 \mathrm{mmol}$ ) was added and the solution stirred for $15 \mathrm{~min}$. To this mixture $\mathrm{LiBr}(114 \mathrm{mg}, 1.31 \mathrm{mmol})$ was added. The solution was warmed to room temperature and stirred for $15 \mathrm{~min}$. 2-[2-(2-Methoxyethoxy)ethoxy]ethyl 2-bromoacetate (374 $\mathrm{mg}, 1.31 \mathrm{mmol}$ ) was added and the reaction mixture was heated to $65^{\circ} \mathrm{C}$ overnight. Concentration under reduced pressure followed by purification by flash chromatography $(9: 1$ $\mathrm{DCM} / \mathrm{MeOH} \mathrm{v} / \mathrm{v}$ ) yielded the product as a colorless oil ( $150 \mathrm{mg}, 0.44 \mathrm{mmol}, 67 \%)$, purity $>85 \%$. 
${ }^{1} \mathrm{H}$ NMR (400 MHz, $\left.\mathrm{CDCl}_{3}\right) \delta 7.04(\mathrm{~s}, 1 \mathrm{H}), 4.87$ (s, 2H), $4.36-4.23(\mathrm{~m}, 2 \mathrm{H}), 3.71-3.65(\mathrm{~m}$, 2H), $3.65-3.57(\mathrm{~m}, 6 \mathrm{H}), 3.55-3.47(\mathrm{~m}, 2 \mathrm{H}), 3.34(\mathrm{~s}, 3 \mathrm{H}) ;{ }^{13} \mathrm{C} \mathrm{NMR}\left(75 \mathrm{MHz}, \mathrm{CDCl}_{3}\right) \delta 168.6$, $163.1,141.1,138.9,125.6,112.4,72.0,70.6,70.6,70.6,68.9,64.6,59.1,46.0,18.0,16.9,16.4$; $v_{\max } / \mathrm{cm}^{-1} 1746,1639,1196,1098$; HRMS (ESI) calcd for $\mathrm{C}_{17} \mathrm{H}_{27} \mathrm{NNaO}_{6}[\mathrm{M}+\mathrm{Na}]^{+} 350.1574$, found 350.1577 .

General procedure for the photooxygenation of 2-pyridones. The respective pyridone was dissolved in ca. $10 \mathrm{~mL}$ DCM in a reaction tube, TPP (1 mg) was added and oxygen was bubbled through the solution with vigorous stirring for $5 \mathrm{~min}$. The mixture was kept under an oxygen atmosphere with a balloon and cooled to $0^{\circ} \mathrm{C}$ and irradiated for $1 \mathrm{~h}$ with a high-pressure sodium lamp. The solution was concentrated in vacuo and the residue was purified by flash column chromatography.

\section{2-[2-(2-Methoxyethoxy)ethoxy]ethyl 2-\{6-oxo-2,3-dioxa-5-azabicyclo[2.2.2] $\quad$ oct-7-en-5-}

yl \}acetate 17. Pyridone 11 (85 mg, $0.28 \mathrm{mmol})$; flash chromatography (20:1 DCM/MeOH v/v) yielded the endoperoxide 17 as a clear oil (90 mg, $271 \mathrm{mmol}, 95 \%){ }^{1} \mathrm{H}$ NMR (400 $\mathrm{MHz}, \mathrm{CDCl}_{3}$ ) ठ $6.96-6.89(\mathrm{~m}, 1 \mathrm{H}), 6.73-6.66(\mathrm{~m}, 1 \mathrm{H}), 5.81-5.77(\mathrm{~m}, 1 \mathrm{H}), 5.01-4.96(\mathrm{~m}, 1 \mathrm{H}), 4.63(\mathrm{~d}, J$ $=18.1 \mathrm{~Hz}, 1 \mathrm{H}), 4.34-4.17(\mathrm{~m}, 2 \mathrm{H}), 3.90(\mathrm{~d}, J=18.1 \mathrm{~Hz}, 1 \mathrm{H}), 3.74-3.43(\mathrm{~m}, 10 \mathrm{H}), 3.33(\mathrm{~s}$, $3 \mathrm{H}) ;{ }^{13} \mathrm{C} \mathrm{NMR}\left(101 \mathrm{MHz}, \mathrm{CDCl}_{3}\right) \delta 168.7,168.0,135.2,127.7,84.5,77.8,71.9,70.5,70.5,70.5$, 68.6, 64.6, 59.0, 43.9; IR $v_{\max } / \mathrm{cm}^{-1} 1744,1704,1447,1202,1098,891$; HRMS (ESI) calculated for $\mathrm{C}_{14} \mathrm{H}_{21} \mathrm{NNaO}_{8}[\mathrm{M}+\mathrm{Na}]^{+}$354.11594, found 354.11597.

\section{2-[2-(2-Methoxyethoxy)ethoxy]ethyl 2-\{1-methyl-6-oxo-2,3-dioxa-5-azabicyclo[2.2.2] oct-7-}

en-5-yl\}acetate 18. Pyridone 12 (90 mg, $0.29 \mathrm{mmol})$; flash chromatography (20:1 DCM/MeOH v/v) yielded the endoperoxide 18 as a slightly purple oil (70 mg, $0.20 \mathrm{mmol}, 70 \%$ ). 
${ }^{1} \mathrm{H}$ NMR $\left(300 \mathrm{MHz}, \mathrm{CDCl}_{3}\right) \delta 6.95(\mathrm{dd}, J=7.8,5.3 \mathrm{~Hz}, 1 \mathrm{H}), 6.45(\mathrm{dd}, J=7.8,1.8 \mathrm{~Hz}, 1 \mathrm{H}), 5.75$ $(\mathrm{dd}, J=5.3,1.8 \mathrm{~Hz}, 1 \mathrm{H}), 4.72(\mathrm{~d}, J=18.1 \mathrm{~Hz}, 1 \mathrm{H}), 4.39-4.20(\mathrm{~m}, 2 \mathrm{H}), 3.92(\mathrm{~d}, J=18.1 \mathrm{~Hz}$, 1H), $3.75-3.49(\mathrm{~m}, 10 \mathrm{H}), 3.38(\mathrm{~s}, 3 \mathrm{H}), 1.62(\mathrm{~s}, 3 \mathrm{H}), 1.56(\mathrm{~s}, 3 \mathrm{H}) ; 4.20(\mathrm{~m}, 2 \mathrm{H}), 3.92(\mathrm{~d}, J=$ $18.1 \mathrm{~Hz}, 1 \mathrm{H}), 3.75-3.49(\mathrm{~m}, 10 \mathrm{H}), 3.38(\mathrm{~s}, 3 \mathrm{H}), 1.62(\mathrm{~s}, 3 \mathrm{H}), 1.56(\mathrm{~s}, 3 \mathrm{H}) ;{ }^{13} \mathrm{C} \mathrm{NMR}(126 \mathrm{MHz}$ $\left.\mathrm{CDCl}_{3}\right) \delta 169.6,168.8,134.7,132.5,84.7,81.3,71.8,70.5,70.5,70.5,68.6,64.5,59.0,44.2$, 14.5; IR $v_{\max } / \mathrm{cm}^{-1} 1747,1705,1448,1201,1104$; HRMS (ESI) calcd for $\mathrm{C}_{15} \mathrm{H}_{23} \mathrm{NNaO}_{8}[\mathrm{M}+\mathrm{Na}]^{+}$ 368.1316, found 368.1316; $\mathrm{R}_{\mathrm{t}}=4.9 \mathrm{~min}(\mathrm{CN}$ modified silica, $10 \%$ iprOH in hexanes, isocratic, 1 $\mathrm{mL} / \mathrm{min}$, then gradient to $40 \% \mathrm{iprOH}$ at $35 \mathrm{~min}$, purity $>95 \%$ )

\section{2-[2-(2-Methoxyethoxy)ethoxy]ethyl 2-\{4-methyl-6-oxo-2,3-dioxa-5-azabicyclo[2.2.2]oct-7-}

en-5-yl\}acetate 19. Pyridone 13 (40 mg, $0.13 \mathrm{mmol}$ ); flash chromatography (20:1 DCM/MeOH $\mathrm{v} / \mathrm{v}$ ) yielded the endoperoxide 19 as a clear oil (42 $\mathrm{mg}, 0.12 \mathrm{mmol}, 95 \%)$.

${ }^{1} \mathrm{H}$ NMR $\left(400 \mathrm{MHz}, \mathrm{CDCl}_{3}\right) \delta 6.72-6.65(\mathrm{~m}, 2 \mathrm{H}), 4.98(\mathrm{dd}, J=4.5,3.3 \mathrm{~Hz}, 1 \mathrm{H}), 4.60(\mathrm{~d}, J=$ $18.2 \mathrm{~Hz}, 1 \mathrm{H}), 4.33-4.15(\mathrm{~m}, 2 \mathrm{H}), 3.94(\mathrm{~d}, J=18.2 \mathrm{~Hz}, 1 \mathrm{H}), 3.73-3.45(\mathrm{~m}, 10 \mathrm{H}), 3.34(\mathrm{~s}, 3 \mathrm{H})$, $1.70(\mathrm{~s}, 3 \mathrm{H}) ;{ }^{13} \mathrm{C} \mathrm{NMR}\left(101 \mathrm{MHz}, \mathrm{CDCl}_{3}\right) \delta 169.2,168.9,140.0,126.8,89.2,77.2,72.0,70.6$, 70.6, 70.6, 68.8, 64.6, 59.1, 40.8, 17.0; IR $v_{\max } / \mathrm{cm}^{-1} 1744,1703,1400,1196,1100,782$; HRMS (ESI) $\mathrm{C}_{15} \mathrm{H}_{23} \mathrm{NNaO}_{8}[\mathrm{M}+\mathrm{Na}]^{+}$368.1316, found 368.1315.

2-[2-(2-Methoxyethoxy)ethoxy]ethyl 2-\{1,8-dimethyl-6-oxo-2,3-dioxa-5-azabicyclo[2.2.2]

oct-7-en-5-yl\}acetate 20. Pyridone 14 (100 mg, $0.305 \mathrm{mmol})$; flash chromatography (20:1 $\mathrm{DCM} / \mathrm{MeOH} \mathrm{v} / \mathrm{v})$ yielded the endoperoxide 20 as a clear oil (82 $\mathrm{mg}, 0.23 \mathrm{mmol}, 75 \%)$.

${ }^{1} \mathrm{H}$ NMR $\left(400 \mathrm{MHz}, \mathrm{CDCl}_{3}\right) \delta 6.03-5.99(\mathrm{~m}, 1 \mathrm{H}), 5.48(\mathrm{~d}, J=2.1 \mathrm{~Hz}, 1 \mathrm{H}), 4.74(\mathrm{~d}, J=18.1$ $\mathrm{Hz}, 1 \mathrm{H}), 4.30-4.25(\mathrm{~m}, 2 \mathrm{H}), 3.85(\mathrm{~d}, J=18.2 \mathrm{~Hz}, 1 \mathrm{H}), 3.68(\mathrm{t}, J=4.7 \mathrm{~Hz}, 2 \mathrm{H}), 3.64-3.58(\mathrm{~m}$, $6 \mathrm{H}), 3.56-3.48(\mathrm{~m}, J=5.7,3.6 \mathrm{~Hz}, 2 \mathrm{H}), 3.35(\mathrm{~s}, 3 \mathrm{H}), 2.07(\mathrm{~d}, J=1.8 \mathrm{~Hz}, 3 \mathrm{H}), 1.54\left(\mathrm{~s}, 3 \mathrm{H}^{13} \mathrm{C}\right.$ NMR (101 MHz, $\left.\mathrm{CDCl}_{3}\right) \delta 170.0,169.1,145.7,125.4,88.9,81.5,72.0,70.7,70.7,70.7,68.8$, 
64.7, 59.1, 44.0, 17.6, 14.6; IR $v_{\max } / \mathrm{cm}^{-1} 1745,1705,1446,1200,1101$; HRMS (ESI) calcd for $\mathrm{C}_{16} \mathrm{H}_{25} \mathrm{NNaO}_{8}[\mathrm{M}+\mathrm{Na}]^{+}$382.1472, found 382.1473.

2-[2-(2-Methoxyethoxy)ethoxy]ethyl 2-\{1,4-dimethyl-6-oxo-2,3-dioxa-5-azabicyclo[2.2.2] oct-7-en-5-yl\}acetate 21. Pyridone 15 (60 mg, $0.18 \mathrm{mmol})$; flash chromatography (20:1 DCM/MeOH v/v) yielded the endoperoxide 21 as a clear oil (64 mg, $0.18 \mathrm{mmol}, 97 \%$ ), purity $>90 \%$.

${ }^{1} \mathrm{H}$ NMR $\left(400 \mathrm{MHz}, \mathrm{CDCl}_{3}\right) \delta 6.66(\mathrm{~d}, J=7.8 \mathrm{~Hz}, 1 \mathrm{H}), 6.38(\mathrm{~d}, J=7.8 \mathrm{~Hz}, 1 \mathrm{H}), 4.60(\mathrm{~d}, J=$ $18.2 \mathrm{~Hz}, 1 \mathrm{H}), 4.32-4.16(\mathrm{~m}, 2 \mathrm{H}), 3.94(\mathrm{~d}, J=18.2 \mathrm{~Hz}, 1 \mathrm{H}), 3.71-3.46(\mathrm{~m}, 10 \mathrm{H}), 3.34(\mathrm{~s}, 3 \mathrm{H})$, $1.67(\mathrm{~s}, 3 \mathrm{H}), 1.57(\mathrm{~s}, 3 \mathrm{H}) ;{ }^{13} \mathrm{C}$ NMR $\left(101 \mathrm{MHz}, \mathrm{CDCl}_{3}\right) \delta 171.2,169.6,139.9,132.1,89.6,81.1$, $72.4,71.1,71.0,71.0,69.3,65.0,59.5,41.7,17.7,15.2 ;$ IR $v_{\max } / \mathrm{cm}^{-1} 1744,1702,1397,1197$ 1102, 790; HRMS (ESI) calcd for $\mathrm{C}_{16} \mathrm{H}_{25} \mathrm{NNaO}_{8}[\mathrm{M}+\mathrm{Na}]^{+}$382.1472, found 382.1473.

2-[2-(2-Methoxyethoxy)ethoxy]ethyl 2-\{1,4,8-trimethyl-6-oxo-2,3-dioxa-5-azabicyclo[2.2.2] oct-7-en-5-yl \}acetate 22. Pyridone 16 (40 $\mathrm{mg}, 0.13 \mathrm{mmol})$ flash chromatography (20:1 DCM/MeOH v/v) yielded the endoperoxide 22 as a clear oil (31 mg, $0.08 \mathrm{mmol}, 95 \%)$, purity $>90 \%$.

${ }^{1} \mathrm{H}$ NMR $\left(300 \mathrm{MHz}, \mathrm{CDCl}_{3}\right) \delta 6.08-6.04(\mathrm{~m}, 1 \mathrm{H}), 4.71(\mathrm{~d}, J=18.3 \mathrm{~Hz}, 1 \mathrm{H}), 4.37-4.19(\mathrm{~m}$, 2H), $3.92(\mathrm{~d}, J=18.3 \mathrm{~Hz}, 1 \mathrm{H}), 3.76-3.48(\mathrm{~m}, 10 \mathrm{H}), 3.38(\mathrm{~s}, 3 \mathrm{H}), 1.97(\mathrm{~d}, J=1.8 \mathrm{~Hz}, 3 \mathrm{H}), 1.64$ (s, 3H), $1.56(\mathrm{~s}, 3 \mathrm{H}) ;{ }^{13} \mathrm{C} \mathrm{NMR}\left(101 \mathrm{MHz}, \mathrm{CDCl}_{3}\right) \delta 171.1,169.5,148.1,125.7,91.4,80.8,72.1$, $71.9,70.7,68.9,64.7,59.2,59.1,41.3,16.2,15.1,14.9 ;$ IR $v_{\max } / \mathrm{cm}^{-1} 1745,1703,1397,1194$ 1096; HRMS (ESI) calcd for $\mathrm{C}_{17} \mathrm{H}_{27} \mathrm{NNaO}_{8}[\mathrm{M}+\mathrm{Na}]^{+} 396.1630$, found 396.1631.

Statistics. For data analysis GraphPad Prism 5.04 software was used and all data were expressed as mean and standard error of the mean. To determine the differences between the different 
conditions one-way respectively two-way analysis of variance (ANOVA) with a Bonferroni posthoc test was performed for the numeric data. A p value of $<0.05$ was considered significant. $*$ denotes $\mathrm{p}<0.05, * *$ denotes $\mathrm{p}<0.01, * * *$ denotes $\mathrm{p}<0.001, * * * *$ denotes $\mathrm{p}<0.0001$

\section{ASSOCIATED CONTENT}

NMR-Spectra, exponential decay curves and cell micrographs. This material is available free of charge via the Internet at http://pubs.acs.org

\section{AUTHOR INFORMATION}

\section{Corresponding Author}

* Dr. Henning Jacob Jessen, University of Zürich, Institute of Organic Chemistry, Winterthurerstrasse 190, 8057 Zürich, Switzerland; e-mail: henningjacob.jessen@uzh.ch; phone: $+41446354241$

* PD Dr. Dr. Daniel Eberli, University of Zürich, Universitätsspital Zürich, Klinik für Urologie, Frauenklinikstrasse 10, 8091 Zürich, Switzerland; e-mail: Daniel.Eberli@usz.ch; phone: +41 44 2559619

Dr. Eberli and Dr. Jessen both serve as last authors. Justification: this work was only possible through combination of the distinct knowledge of two research groups (Dr. Eberli - Cellwork, Tissue Engineering, Dr. Jessen - Chemistry). 


\section{Present Addresses}

$\dagger$ Professor Jay S. Siegel, Dean; School of Pharmaceutical Science and Technology; Tianjin University (A210/Bldg 24); 92 Weijin Road, Nankai District; Tianjin, 300072 PRC

\section{Author Contributions}

The manuscript was written through contributions of all authors. All authors have given approval to the final version of the manuscript. $\ddagger$ These authors contributed equally.

\section{Funding Sources}

This work was funded by the Fonds der Chemischen Industrie (FCI, Germany), the Swiss National Science Foundation (SNF) and the University of Zürich (UZH).

\section{Notes}

Normoxic conditions are generally referred to as $21 \%$ oxygen, hypoxic conditions $1-5 \%$ oxygen and anoxic conditions $<1 \%$ oxygen. It should be noted that most cells behave differently under hypoxic conditions found in their respective tissue as compared to normoxia, which is hardly the oxygen partial pressures most cells are exposed to. One needs to be aware of the fact that normoxia $\left(21 \% \mathrm{O}_{2}\right)$ is in fact for most cells a hyperoxic condition and hypoxic conditions are actually representative of an in situ normoxia for many cells. ${ }^{51}$

\section{ACKNOWLEDGMENT}

Generous financial support from the FCI (Liebig Stipend to H.J.J.) and the SNF (SNF, Ambizione Grant PZ00P2_136816 to H.J.J.) is acknowledged. We want to thank the members of the MS and NMR facilities at the University of Zürich (Laurent Bigler and Oliver Zerbe). 
J.S.S. gratefully acknowledges the Swiss National Science Foundation (SNSF), the Qian Ren Scholar Program of P.R.China, and Synergetic Innovation Center of Chemical Science and Engineering (Tianjin).

\author{
ABBREVIATIONS \\ VEGF, Vascular endothelial growth factor; HIF-1, hypoxia-inducible factor 1; FB, 3T3 \\ fibroblasts; SMC, smooth muscle cell; TLC, thin layer chromatography; NMR, nuclear magnetic \\ resonance; $\mathrm{MS}$, mass spectrometry; TBCA, tribromoisocyanuric acid; $m \mathrm{CPBA}$, meta- \\ chloroperbenzoic acid; DMSO, dimethyl sulfoxide; DMF, dimethyl formamide; DME, \\ dimethoxyethane; TBCA, tribromoisocyanuric acid; TPP, tetraphenyl porphyrin, Vit. C, vitamin \\ C; SOSG, singlet oxygen sensor green.
}

\title{
REFERENCES
}

(1) Folkman, J.; Hochberg, M. Self-regulation of growth in three dimensions. J. Exp. Med. 1973, $138,745-753$.

(2) Griffith, C. K.; Miller, C.; Sainson, R. C. A.; Calvert, J. W.; Jeon, N. L.; Hughes, C. C. W.; George, S. C. Diffusion limits of an in vitro thick prevascularized tissue. Tissue Eng. 2005, $11,257-266$.

(3) Liu, J.; Barradas, A.; Fernandes, H.; Janssen, F.; Papenburg, B.; Stamatialis, D.; Martens, A.; van Blitterswijk, C.; de Boer, J. In vitro and in vivo bioluminescent imaging of hypoxia in tissue-engineered grafts. Tissue Eng. Part C Methods 2010, 16, 479-485. 
(4) Radisic, M.; Malda, J.; Epping, E.; Geng, W.; Langer, R.; Vunjak-Novakovic, G. Oxygen gradients correlate with cell density and cell viability in engineered cardiac tissue. Biotechnol Bioeng. 2006, 93, 332-343.

(5) Radisic, M.; Park, H.; Chen, F.; Salazar-Lazzaro, J. E.; Wang, Y.; Dennis, R.; Langer, R.; Freed, L. E.; Vunjak-Novakovic, G. Biomimetic approach to cardiac tissue engineering: oxygen carriers and channeled scaffolds. Tissue Eng. 2006, 12, 2077-2091.

(6) Vunjak-Novakovic, G.; Tandon, N.; Godier, A.; Maidhof, R.; Marsano, A.; Martens, T. P.; Radisic, M. Challenges in cardiac tissue engineering. Tissue Eng. Part B Rev 2010, 16, 169187.

(7) Wendt, D.; Stroebel, S.; Jakob, M.; John, G. T.; Martin, I. Uniform tissues engineered by seeding and culturing cells in 3D scaffolds under perfusion at defined oxygen tensions. Biorheology 2006, 43, 481-488.

(8) Auger, F. A.; Gibot, L.; Lacroix, D. The pivotal role of vascularization in tissue engineering. Annu. Rev. Biomed. Eng. 2013, 15, 177-200.

(9) Montano, I.; Schiestl, C.; Schneider, J.; Pontiggia, L.; Luginbuhl, J.; Biedermann, T.; Bottcher-Haberzeth, S.; Braziulis, E.; Meuli, M.; Reichmann, E. Formation of human capillaries in vitro: the engineering of prevascularized matrices. Tissue Eng. Part A 2010, 16, 269-282.

(10) Tsigkou, O.; Pomerantseva, I.; Spencer, J. A.; Redondo, P. A.; Hart, A. R.; O'Doherty, E.; Lin, Y.; Friedrich, C. C.; Daheron, L.; Lin, C. P.; Sundback, C. A.; Vacanti, J. P.; Neville, C. Engineered vascularized bone grafts. Proc. Natl. Acad. Sci. U S A 2010, 107, 3311-3316. 
(11) Carmeliet, P.; Jain, R. K. Angiogenesis in cancer and other diseases. Nature 2000, 407, 249-257.

(12) Semenza, G. L. Life with oxygen. Science 2007, 318, 62-64.

(13) Semenza, G. L. Oxygen-dependent regulation of mitochondrial respiration by hypoxiainducible factor 1. Biochem. J. 2007, 405, 1-9.

(14) Benjamin, S.; Sheyn, D.; Ben-David, S.; Oh, A.; Kallai, I.; Li, N.; Gazit, D.; Gazit, Z. Oxygenated environment enhances both stem cell survival and osteogenic differentiation. Tissue Eng. Part A 2013, 19, 748-758.

(15) Khan, M.; Kwiatkowski, P.; Rivera, B. K.; Kuppusamy, P. Oxygen and oxygenation in stem-cell therapy for myocardial infarction. Life Sci. 2010, 87, 269-274.

(16) Khan, M.; Kutala, V. K.; Vikram, D. S.; Wisel, S.; Chacko, S. M.; Kuppusamy, M. L.; Mohan, I. K.; Zweier, J. L.; Kwiatkowski, P.; Kuppusamy, P. Skeletal myoblasts transplanted in the ischemic myocardium enhance in situ oxygenation and recovery of contractile function. Am. J. Physiol-Heart C 2007, 293, H2129-H2139.

(17) Harrison, B. S.; Eberli, D.; Lee, S. J.; Atala, A.; Yoo, J. J. Oxygen producing biomaterials for tissue regeneration. Biomaterials 2007, 28, 4628-4634.

(18) Li, Z. Q.; Guo, X. L.; Guan, J. J. An oxygen release system to augment cardiac progenitor cell survival and differentiation under hypoxic condition. Biomaterials 2012, 33, 5914-5923. 
(19) Oh, S. H.; Ward, C. L.; Atala, A.; Yoo, J. J.; Harrison, B. S. Oxygen generating scaffolds for enhancing engineered tissue survival. Biomaterials 2009, 30, 757-762.

(20) Pedraza, E.; Coronel, M. M.; Fraker, C. A.; Ricordi, C.; Stabler, C. L. Preventing hypoxia-induced cell death in beta cells and islets via hydrolytically activated, oxygengenerating biomaterials. Proc. Natl. Acad. Sci. U S A 2012, 109, 4245-4250.

(21) Tremblay, P. L.; Hudon, V.; Berthod, F.; Germain, L.; Auger, F. A. Inosculation of tissue-engineered capillaries with the host's vasculature in a reconstructed skin transplanted on mice. Am. J. Transplant. 2005, 5, 1002-1010.

(22) Waite, A. J.; Bonner, J. S.; Autenrieth, R. Kinetics and stoichiometry of oxygen release from solid peroxides. Environ. Eng. Sci. 1999, 16, 187-199.

(23) Mooney, D. J.; Sano, K.; Kaufmann, P. M.; Majahod, K.; Schloo, B.; Vacanti, J. P.; Langer, R. Long-term engraftment of hepatocytes transplanted on biodegradable polymer sponges. J. Biomed. Mater. Res. 1997, 37, 413-420.

(24) Yang, L.; Zhu, L.; Dong, W.; Cao, Y.; Rong, Z. Oxygen-generating scaffolds: A new strategy for bone tissue engineering. Bone 2013, 57, 322-323.

(25) Northup, A.; Cassidy, D. Calcium peroxide (CaO2)for use in modified Fenton chemistry. J. Hazard. Mater. 2008, 152, 1164-1170.

(26) Dufraisse, C.; Etienne, A. Separable organic oxides - The anthracenic structure is endowed with the reversible oxidizability of separable mesenteriolum diphenyl anthracene oxide. Cr. Hebd. Acad. Sci. 1935, 201, 280-282. 
(27) Dewilde, A.; Pellieux, C.; Hajjam, S.; Wattre, P.; Pierlot, C.; Hober, D.; Aubry, J. M. Virucidal activity of pure singlet oxygen generated by thermolysis of a water-soluble naphthalene endoperoxide. J. Photochem. Photobiol. B 1996, 36, 23-29.

(28) Fudickar, W.; Linker, T. Why triple bonds protect acenes from oxidation and decomposition. J. Am. Chem. Soc. 2012, 134, 15071-15082.

(29) Matsumoto, M.; Yamada, M.; Watanabe, N. Reversible 1,4-cycloaddition of singlet oxygen to N-substituted 2-pyridones: 1,4-endoperoxide as a versatile chemical source of singlet oxygen. Chem. Commun. 2005, 483-485.

(30) Pierlot, C.; Aubry, J. M.; Briviba, K.; Sies, H.; Di Mascio, P. Naphthalene endoperoxides as generators of singlet oxygen in biological media. Methods Enzymol. 2000,319, 3-20.

(31) Wiegand, C.; Herdtweck, E.; Bach, T. Enantioselectivity in visible light-induced, singlet oxygen [2+4] cycloaddition reactions (type II photooxygenations) of 2-pyridones. Chem. Commun. 2012, 48, 10195-10197.

(32) Schweitzer, C.; Schmidt, R. Physical mechanisms of generation and deactivation of singlet oxygen. Chem. Rev. 2003, 103, 1685-1757.

(33) Jensen, R. L.; Arnbjerg, J.; Ogilby, P. R. Temperature effects on the solvent-dependent deactivation of singlet oxygen. J. Am. Chem. Soc. 2010, 132, 8098-8105.

(34) Sato, E.; Ikeda, Y.; Kanaoka, Y. Photochemistry of Conjugated Nitrogen Carbonyl Systems .3. Photosensitized Oxygenation of 3-Substituted and 6-Substituted 2-Pyridones. Chem. Pharm. Bull. 1987, 35, 507-513. 
(35) Saito, I.; Matsuura, T.; Inoue, K. Formation of Superoxide Ion from Singlet Oxygen - on the Use of a Water-Soluble Singlet Oxygen Source. J. Am. Chem. Soc. 1981, 103, 188-190.

(36) Hoffman, J. M.; Wai, J. S.; Thomas, C. M.; Levin, R. B.; Obrien, J. A.; Goldman, M. E. Synthesis and Evaluation of 2-Pyridinone Derivatives as Hiv-1 Specific Reverse-Transcriptase Inhibitors .1. Phthalimidoalkyl and Phthalimidoalkylamino Analogs. J. Med. Chem. 1992, 35, 3784-3791.

(37) de Almeida, L. S.; Esteves, P. M.; de Mattos, M. C. S. Tribromoisocyanuric acid: A new reagent for regioselective cobromination of alkenes. Synlett 2006, 1515-1518.

(38) Yao, Y. X.; Lamba, J. J. S.; Tour, J. M. Synthesis of highly functionalized pyridines for planar polymers. Maximized pi-conjugation in electron deficient macromolecules. J. Am. Chem. Soc. 1998, 120, 2805-2810.

(39) Mittelbach, M.; Schmidt, H. W.; Uray, G.; Junek, H.; Lamm, B.; Ankner, K.; Brandstrom, A.; Simonsson, R. Synthesis of 4-methoxy-2,3,5-trimethylpyridine: a specific building block for compounds with gastric-acid inhibiting activity. Acta Chem. Scand. B 1988, $42,524-529$.

(40) Bain, B. M.; Saxton, J. E. Reaction of Nicotinic Acid 1-Oxide and 3-Picoline 1-Oxide with Acetic Anhydride. J. Chem. Soc. 1961, 5216-\&.

(41) Morrissey, S.; Pegot, B.; Coleman, D.; Garcia, M. T.; Ferguson, D.; Quilty, B.; Gathergood, N. Biodegradable, non-bactericidal oxygen-functionalised imidazolium esters: A step towards 'greener' ionic liquids. Green Chem. 2009, 11, 475-483. 
(42) Liu, H.; Ko, S. B.; Josien, H.; Curran, D. P. Selective N-Functionalization of 6Substituted-2-Pyridones. Tetrahedron Lett. 1995, 36, 8917-8920.

(43) DeRosa, M. C.; Crutchley, R. J. Photosensitized singlet oxygen and its applications. Coordin. Chem.Rev. 2002, 233, 351-371.

(44) Jana, C. K.; Hoecker, J.; Woods, T. M.; Jessen, H. J.; Neuburger, M.; Gademann, K. Synthesis of Withanolide A, Biological Evaluation of Its Neuritogenic Properties, and Studies on Secretase Inhibition. Angew. Chem. Int. Edit. 2011, 50, 8407-8411.

(45) Horst, M.; Madduri, S.; Milleret, V.; Sulser, T.; Gobet, R.; Eberli, D. A bilayered hybrid microfibrous PLGA--acellular matrix scaffold for hollow organ tissue engineering. Biomaterials 2013, 34, 1537-1545.

(46) Kornblum, N.; Delamare, H. E. The Base Catalyzed Decomposition of a Dialkyl Peroxide. J. Am. Chem. Soc. 1951, 73, 880-881.

(47) Staben, S. T.; Xin, L. H.; Toste, F. D. Enantioselective synthesis of gammahydroxyenones by chiral base-catalyzed Kornblum DeLaMare rearrangement. J. Am. Chem. Soc. 2006, $128,12658-12659$.

(48) Karamariti, E.; Margariti, A.; Winkler, B.; Wang, X.; Hong, X.; Baban, D.; Ragoussis, J.; Huang, Y.; Han, J. D.; Wong, M. M.; Sag, C. M.; Shah, A. M.; Hu, Y.; Xu, Q. Smooth muscle cells differentiated from reprogrammed embryonic lung fibroblasts through DKK3 signaling are potent for tissue engineering of vascular grafts. Circ. Res. 2013, 112, 1433-1443.

(49) Margariti, A.; Zeng, L.; Xu, Q. Stem cells, vascular smooth muscle cells and atherosclerosis. Histol. Histopathol. 2006, 21, 979-985. 
(50) Montesano, R.; Pepper, M. S.; Orci, L. Paracrine Induction of Angiogenesis in-Vitro by Swiss 3t3 Fibroblasts. J. Cell Sci. 1993, 105, 1013-1024.

(51) Ivanovic, Z. Hypoxia or in situ normoxia: The stem cell paradigm. J. Cell Physiol. 2009, $219,271-275$.

(52) Chen, B.; Calvert, A. E.; Cui, H.; Nelin, L. D. Hypoxia promotes human pulmonary artery smooth muscle cell proliferation through induction of arginase. Am. J. Physiol. Lung Cell Mol. Physiol. 2009, 297, L1151-1159.

(53) Steinbrech, D. S.; Longaker, M. T.; Mehrara, B. J.; Saadeh, P. B.; Chin, G. S.; Gerrets, R. P.; Chau, D. C.; Rowe, N. M.; Gittes, G. K. Fibroblast response to hypoxia: the relationship between angiogenesis and matrix regulation. J. Surg. Res. 1999, 84, 127-133.

(54) Semenza, G. L. Hypoxia-inducible factor 1: master regulator of O-2 homeostasis. Curr Opin. Genet. Dev. 1998, 8, 588-594.

(55) Papandreou, I.; Powell, A.; Lim, A. L.; Denko, N. Cellular reaction to hypoxia: sensing and responding to an adverse environment. Mutat. Res-Fund. Mol. M. 2005, 569, 87-100.

(56) Douglas, R. M.; Haddad, G. G. Genetic models in applied physiology - Invited review: Effect of oxygen deprivation on cell cycle activity: a profile of delay and arrest. J. Appl. Physiol. 2003, 94, 2068-2083.

(57) Weishaupt, K. R.; Gomer, C. J.; Dougherty, T. J. Identification of Singlet Oxygen as Cytotoxic Agent in Photo-Inactivation of a Murine Tumor. Cancer Res. 1976, 36, 2326-2329. 
(58) Bisby, R. H.; Morgan, C. G.; Hamblett, I.; Gorman, A. A. Quenching of singlet oxygen by Trolox C, ascorbate, and amino acids: Effects of $\mathrm{pH}$ and temperature. J. Phys. Chem. A 1999, $103,7454-7459$.

(59) Gollmer, A.; Arnbjerg, J.; Blaikie, F. H.; Pedersen, B. W.; Breitenbach, T.; Daasbjerg, K.; Glasius, M.; Ogilby, P. R. Singlet Oxygen Sensor Green(R): photochemical behavior in solution and in a mammalian cell. Photochem. Photobiol. 2011, 87, 671-679.

(60) Celli, J. P.; Spring, B. Q.; Rizvi, I.; Evans, C. L.; Samkoe, K. S.; Verma, S.; Pogue, B. W.; Hasan, T. Imaging and Photodynamic Therapy: Mechanisms, Monitoring, and Optimization. Chem. Rev. 2010, 110, 2795-2838.

(61) Dolmans, D. E. J. G. J.; Fukumura, D.; Jain, R. K. Photodynamic therapy for cancer. Nat. Rev. Cancer 2003, 3, 380-387.
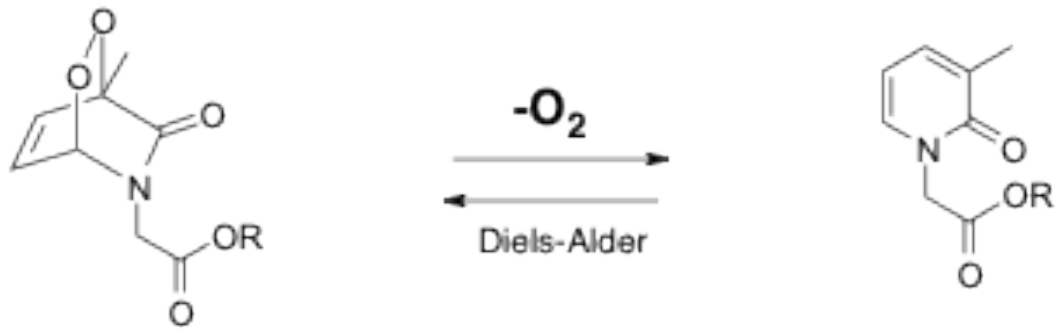

TOC. Retro Diels-Alder reaction generating oxygen from pyridone endoperoxides 